\title{
Separate and Combined Effects of Hydrogen and Nitrogen Additions on Diesel Engine Combustion
}

\author{
Raouf Mobasheri ${ }^{1}$, Mahdi Seddiq ${ }^{1}$, Zhijun Peng ${ }^{2 *}$ \\ ${ }^{1}$ Department of Mechanical Engineering, University of Ayatollah ozma Boroujerdi, Iran \\ ${ }^{2}$ Faculty of Creative Arts, Technologies and Science, University of Bedfordshire, UK \\ *Corresponding Author: Faculty of Creative Arts, Technologies and Science, University of Bedfordshire, UK, \\ jun.peng@beds.ac.uk
}

\begin{abstract}
Shortage of non-renewable energies, increase in fossil fuel prices and stricter emissions regulations due to high NOx and soot emissions emitted from combustion of heavy diesel fuels by compression ignition engines, has led consumers to use renewable, cleaner and cheap fuels. An investigation has been computationally carried out to explore the influences of hydrogen and nitrogen addition on engine performance such as indicated power and indicated specific energy consumption and amounts of pollutant emissions like NOx, soot, and CO in an HSDI (High-Speed Direct Injection) diesel engine. Optimized sub-models, such as turbulence model, spray model, combustion model and emissions models have selected for the main CFD code. Meanwhile, HF (Homogeneity Factor) has been employed for analysing in-cylinder air-fuel mixing quality under various addition conditions. After validations with experimental data of diesel combustion with a single addition of $4 \%$ hydrogen and combined addition of $6 \%$ hydrogen $+6 \%$ nitrogen, investigations have conducted for modelling mixing and combustion processes with additions of hydrogen and nitrogen by ranges of $2 \%$ to $8 \%(\mathrm{v} / \mathrm{v})$. Results showed that a single addition of $\mathrm{H}_{2}$ increased NOx and decreased CO and soot and improved ISEC and IP. In the case of nitrogen addition, NOx decreased, both $\mathrm{CO}$ and soot emission increased and ISEC and IP considerably ruined compared with NDC operation. Based on the results obtained for simultaneous addition of $\mathrm{N}_{2}(8 \%$ of $\mathrm{v} / \mathrm{v})$ and $\mathrm{H}_{2}(8 \%$ of $\mathrm{v} / \mathrm{v})$, NOx and soot emissions decreased by $11.5 \%$ and $42.5 \%$ respectively, and ISEC and IP improved $25.7 \%$ and $13 \%$, respectively. But amount of CO emissions had an increase of 52\% should be paid ncecessary attention as a main disadvantage.
\end{abstract}

Keywords: CFD Simulation, HSDI Diesel Engine, Combustion, Emissions, Hydrogen, Nitrogen 


\section{Introduction}

Lower fuel consumption, high thermal efficiency, and more power density and durability have made diesel engines more applicable than spark ignition and gas engines [1]. Over the past several years, due to a high level of the pollutant emissions such as NOx, soot and CO produced by diesel engines lots of efforts have been made to make the combustion of compression ignition engines cleaner. Many types of research have been carried out to improve engine performance while decreasing amount of pollutant emissions in diesel engines. Usage of high injection pressure [2-3], changing the injection profile [4-5], applying the split and multiple injections [6-7], changing the fuel spray angle and the number of injection holes [8-9], recirculating the part of the exhaust gas into the combustion chamber (EGR) [10], varying the swirl ratio [11] and changing the combustion chamber geometry [12] are the common used strategies that their positive and adverse effects have discussed in many papers.

Shortage of non-renewable energies and increase in fuel prices such as diesel and gasoline causes the development of a new study field which deals with the investigation the effects of biofuels and fuel additives on the diesel engines parameters. Many researchers have studied the effects of various fuels and fuel additives such as natural gas [13-14], syngas [15], Iso-Butanol [16-17], propane [18] and hydrogen gas [19-20] on engine performance and amounts of output emissions. In their study, Chun et al. have investigated the influence of $\mathrm{H}_{2}$ gas addition on the emissions formation and performance of a diesel engine [21]. They have indicated that substitution of $\mathrm{H}_{2}$ gas for diesel fuel have made the premixed burn fraction larger and also the amounts of Nitrogen Oxides (NOx) and Particulate Matter (PM) have decreased simultaneously. In their experimental study, Karagöz et al. [22] injected $\mathrm{H}_{2}$ fuel into intake manifold using LPG-CNG injector, while diesel fuel was injected directly into a cylinder using highpressure injection system that is controlled by an engine control unit. They examined the influence of various hydrogen energy fractions $0 \%$ (pure diesel), 22\%, and 53\% of total fuel energy (hydrogen + diesel fuel) on smoke, NOx, CO, UHC emissions, performance (BSFC and brake thermal efficiency), and combustion characteristics (in-cylinder pressure and heat release rate) in a diesel engine at 1100 RPM constant speed. Their results showed that by increasing hydrogen energy fraction $\mathrm{CO}$ and smoke emissions considerably decreased. However, UHC slightly increased, and also NOx emissions have grown by increasing the percentage of hydrogen energy portion. They also included that peak of in-

cylinder pressure rose by $7.8 \%$ and $36.2 \%$ with $22 \%$ and $53 \%$ hydrogen energy fraction addition in comparison to neat diesel combustion. Furthermore, a $25.77 \%$ growth in peak heat release rate acquired with $22 \%$ hydrogen energy portion.

Talibi et al. [23] have provided a discussion of the effects of hydrogen gas fuel addition on combustion characteristics, emissions formation and engine performance in a naturally aspirated high-speed direct 
injection compression ignition engine. They have reported that with fixed diesel fuel injection periods and increasing hydrogen gas addition, particulates, $\mathrm{CO}$, and UHC emissions have decreased. However, NOx emissions have increased by increasing $\mathrm{H}_{2}$ due to increase in diesel-hydrogen co-combustion temperature. Deb et al. [24] have studied the effects of various hydrogen energy fractions on combustion, performance, and emissions formation in a single cylinder, dual fuel direct injection diesel engine at 1500 RPM engine speed and 5.2 KW consistent indicated power. The hydrogen energy fraction was varied from $0 \%$ (neat diesel combustion), 11\%, 17\%, 30\% and 42\%. According to their obtained results, increasing hydrogen energy fraction accompanied with improvement of brake thermal efficiency of the engine and reduction in brake specific energy consumption. They have also indicated that, by increasing hydrogen energy fraction $\mathrm{CO}, \mathrm{CO}_{2}$ and smoke emissions have decreased and due to increase in combustion temperature of dual fuel combustion process, NOx emissions have increased. Furthermore, they have observed a sharp increase in peak in-cylinder pressure and rate of heat release with the increasing hydrogen energy fraction.

In other research, Sandalci and Karagöz [25] experimentally have explored the effects of hydrogen addition on combustion characteristics, emissions formation, and performance of a diesel engine. They have varied hydrogen gas energy fraction from $0 \%$ (pure diesel fuel combustion), $16 \%, 36 \%$ and $46 \%$ at 1300 RPM constant engine speed and $5.1 \mathrm{KW}$ of constant indicated power. According to their experimental results, by increasing the hydrogen gas fuel, energy fraction indicated thermal efficiency have decreased, and isfc (indicated specific fuel consumption) have increased simultaneously. Regarding emissions formation, they showed that $\mathrm{CO}, \mathrm{CO}_{2}$ and smoke emissions decreased by increasing $\mathrm{H}_{2}$ gas energy fraction. However, NOx emissions have not changed at 16\% hydrogen energy portion. Furthermore, they have shown that peak of in-cylinder pressure and rate of heat release have increased with the increasing $\mathrm{H}_{2}$ energy fraction. In their paper, Yang et al. [26] carried out multidimensional computations on the effects of $\mathrm{H}_{2}$ gas addition on combustion characteristics and emissions formation of Cummins ISM370 diesel engine at 70\% load. Their numerical results have shown that by increasing the percentage of $\mathrm{H}_{2}$ gas addition, the cylinder pressure and rate of heat release first increased and then decreased. Regarding emissions formation, NO emissions have increased, while PM emissions decreased. They have also indicated that both the pressure and heat release rate has reached the maximum value at the addition of $17 \% \mathrm{H}_{2}$.

Zho, Cheung, and Leung [27] conducted an experimental study on the influence of hydrogen energy fractions on combustion characteristics, performance, regulated and unregulated emissions of a diesel engine by varying energy fraction from $10 \%, 20 \%, 30 \%$, and $40 \%$ of the total fuel. They have reported that, at $90 \%$ load and more than $30 \%$ hydrogen addition, due to the drastic increase in peak heat release rate, shortened ignition delay, and combustion duration, abnormal combustion have occurred. They have 
indicated that $\mathrm{CO} / \mathrm{CO}_{2}$ and seven kinds of unregulated emissions can considerably reduce. Furthermore, more than $30 \%$ of hydrogen addition can reduce the UHC emissions at low to medium loads. They have also shown that the percentage reduction of NOx emissions is engine load dependent, being positive at low loads and negative at high loads. Jheng and co-workers [28] have investigated the effects of a conventional diesel engine through the addition of $\mathrm{H}_{2}$ mixture, generated through water electrolysis. In their work, three different diesel-hydrogen blend ratios $0 \%$ (neat diesel combustion), $0.6 \%$ and $1.2 \%$ used. Experimental tests were carried out at the idling condition under constant speed from the low to high engine load with different amount of hydrogen gas fuel mixture. Their experimental results have shown an improvement in Brake Thermal Efficiency (BTE) and Brake Specific Fuel Consumption (BSFC) with an increasing amount of $\mathrm{H}_{2}$. Furthermore, increasing the amount of $\mathrm{H}_{2}$ gas mixture have reduced the carbon dioxide and carbon monoxide emissions simultaneously and also at high load operation, the reduction of emissions was the most significant. However, the unburnt hydrocarbon emissions have been increased $4.94 \%$ and $13.1 \%$ on average with the low level of hydrogen gas addition ( $0.6 \%$ and $1.2 \%$ by volume). In their numerical research work, An et al. [29] have explored the influence of hydrogen gas fuel induction to the combustion chamber of a diesel engine by using multidimensional CFD Code KIVA4 coupled with CHEMKIN software. They have reported that, at low engine speeds, the Indicated Thermal Efficiency (ITE), in-cylinder pressure and apparent rate of heat release have increased considerably with the induction of $\mathrm{H}_{2}$ gas. They found that addition of hydrogen gas at high engine speed and high load operation has no tangible effect on the engine performance and combustion characteristics. They have indicated that $\mathrm{CO}$ and soot emissions have decreased under most of the engine operating conditions. However, NOx emissions have increased at a low engine speed of 1600 RPM. Gazal [30] has demonstrated that applying hydrogen as an extra fuel, which can be added to diesel fuel in the (IC) engine results in improvement of engine performance and reduction of emissions compared to clean diesel combustion because this measure approaches the combustion process to constant volume.

As indicated in the literature, induction of $\mathrm{H}_{2}$ gas could lead to a reduction of soot, $\mathrm{CO}$, and UHC emissions but, at the same time, it may have some adverse effects on the amount of NOx emissions due to higher temperature combustion. As a result, the different strategies recently have investigated the effects of different additive accompanied with $\mathrm{H}_{2}$ gas (e.g., methane, $\mathrm{CO}, \mathrm{N}_{2}$, and also diesel combustion) to reduce NOx emission and maintain combustion temperature at an appropriate level. In their experimental research, Talibi et al. [31] have investigated the addition of methane-hydrogen which pilot-ignited by diesel fuel injection in a naturally aspirated, direct injection diesel engine. Their results showed that at any engine loads, $\mathrm{CO}$ and UHC emissions were higher for methane-hydrogen mixtures compared to clean diesel combustion. They also have indicated that, by increasing proportion of hydrogen in $\mathrm{H}_{2}-\mathrm{CH}_{4}$ mixtures, the NOx emissions increased at all engine loads. Mohamad et al. [32] have studied the effects of 
varying $\mathrm{H}_{2}-\mathrm{CH}_{4}$ mixture ratio $(0 \%-100 \%, 30 \%-70 \%, 50 \%-50 \%, 70 \%-30 \%$ and $100 \%-0 \%)$ on the combustion characteristics and emissions of direct injection compression ignition engine. They have reported that only addition of methane gas into the cylinder leads to increase ignition delay but as the ratio of $\mathrm{H}_{2}$ in the $\mathrm{H}_{2}-\mathrm{CH}_{4}$ increases, the maximum point of mean in-cylinder pressure increase linearly and considerably. They also have demonstrated that increasing $\mathrm{H}_{2}$ ratio linearly increase NO emission, but increasing $\mathrm{CH}_{4}$ ratio leads to a considerable increase in $\mathrm{CO}$ level. They showed that to maintain low combustion temperature, higher diesel content is preferable to gain higher thermal efficiency by avoiding excessive heat loss. In their paper, Tarabet et al. [33] have investigated the improvement of direct injection diesel engine operating at $1500 \mathrm{rpm}$ and under dual fuel mode with biodiesel and a natural gas enriched by various $\mathrm{H}_{2}$ quantities $\left(15,25\right.$ and 30 by v\%). They compared the effect of $\mathrm{H}_{2}$-Natural gas blending ratio on the combustion parameters, performance, and emissions formation of the engine with clean natural gas combustion case. Thay has shown that, with the $25 \% \mathrm{H}_{2}$ blend compared to the clean natural gas case, brake specific fuel consumption decreased to 4 to $10 \%$. Also, they have indicated that natural gas enrichment with $\mathrm{H}_{2}$ is the efficient solution to enhance the combustion process and hence reduce $\mathrm{CO}$, UHC, and soot emissions at high loads. Alrazen et al. [34] have studied the influence of $\mathrm{H}_{2}$, $\mathrm{CNG}$, and diesel blend on combustion characteristics and emissions formation of a diesel engine using two-dimensional CFD code. Their results have shown that the peak in-cylinder pressure and peak temperature were increased with the addition of gaseous fuels at low and medium values of exceeds air. In addition, compared with Diesel- $\mathrm{H}_{2}$ (70\%)-Compressed Natural gas (30\%) for tri-mode and Diesel-H2 for dual mode, it is observed that there were no effects on the peak temperature at high exceed air. They have reported that Diesel- $\mathrm{H}_{2}-\mathrm{CNG}$ operations decrease $\mathrm{CO} / \mathrm{CO} 2$ emissions compared with Diesel-CNG operation and decrease NO emission compared with the Diesel- $\mathrm{H}_{2}$ operation. In their work, Christodoulou and Megaritis [35] performed the experimental study on the effects of reformer gas mixture $\left(\mathrm{H}_{2}+\mathrm{CO}+\right.$ $\mathrm{N}_{2}$ ) on the performance and emissions formation of an HSDI diesel engine. They have reported that introduction of $\left(\mathrm{H}_{2}+\mathrm{CO}+\mathrm{N}_{2}\right)$ gas mixture resulted in a simultaneous reduction of the formation of NOx and soot emissions.

Introduction of $\mathrm{CO}$ and diesel combustion due to high specific heat capacity or gaseous fuel additives with high latent heat value such as methane into the cylinder and participate in the combustion process is an effective solution to decrease the adverse effects of hydrogen gas addition on NOx emissions formation by decreasing the maximum point of combustion temperature. Also diluting the intake charge with $\mathrm{N}_{2}$ gas leads to decrease the oxygen level inside the combustion chamber by partially replacing the intake air oxygen with nitrogen gas. Reduction of oxygen level could considerably decrease the NOx emissions at the expense of CO, UHC, and soot emissions. However, in these studies, the effects of nitrogen gas additive has not thoroughly explored and discussed. With these issues as motivation, the 
purpose of this study is to investigate the separate and simultaneous effects of $\mathrm{H}_{2}$ and $\mathrm{N}_{2}$ gas addition in an HSDI diesel engine. For this, the different percentage of hydrogen and nitrogen gases $(2-8 \%$ of total intake charge) have investigated in detail. Also, a modified parameter named 'Homogeneity Factor (HF) of in-cylinder charge' has been applied to study the effects of various strategies on air-fuel mixing and combustion process.

\section{Model Description}

AVL ESE Fire code [36] was used for the diesel-hydrogen combustion simulations. The computational mesh has been created using AVL ESE Diesel Tool and Because of the injector have six holes and the symmetrical location of the injector at the center of the combustion chamber, the CFD calculations are performed on 60 degrees sector meshes. Exhaust and intake ports are not included in the computational mesh by concentrating this simulation on in-cylinder flow and combustion processes. Calculations begin at Intake Valve Closure (IVC) and end at Exhaust Valve Opening (EVO). The ground of the bowl meshed with three continuous layers for a proper calculation of the heat transfer through the piston wall. The same initial and boundary conditions are used for all the computations. To simulate the combustion process with high accuracy, the time step used for calculation is 0.5 degree of crank angle for $2 \mathrm{D}$ and $3 \mathrm{D}$ results. The final mesh consists of a hexahedral dominated mesh. Figure 1(a) shows the computational grids at TDC. As shown in Figure 1(a), three computational grids with a different average cell size were considered for the combustion chamber of the HSDI diesel engine. The baseline operation case of clean diesel combustion mode was simulated with the three computational grids as shown in Figure 1(a). Figure 1(b) shows the influence of the number of computational grid cells on the in-cylinder mean pressure and rate of heat release trends. As indicated in Figure 1(b), for a computational grid with an average cell size of $6 \mathrm{~mm}$, the results obtained from the simulation of the in-cylinder mean pressure and the rate of heat release of the baseline clean diesel combustion case are independent of the number of computational grid cells. For this reason, the computational grid with a $6 \mathrm{~mm}$ average cell size was chosen for performing the rest of the simulations. 


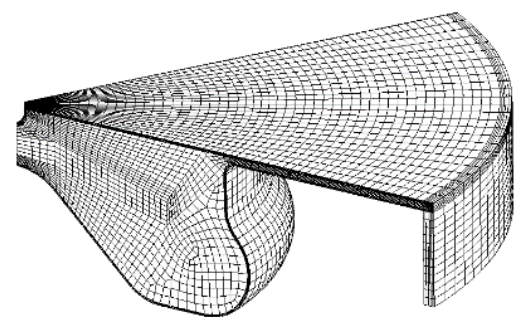

Coarse Grid

TDC: 71135 Cells

BDC: 21568 Cells

Average Cell Size: $8 \mathrm{~mm}$

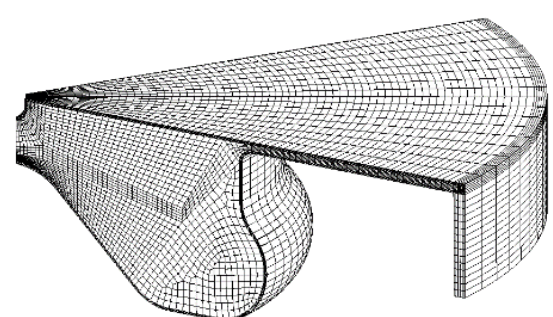

Medium Grid

TDC: 102697 Cells

BDC: 39134 Cells

Average Cell Size: $6 \mathrm{~mm}$

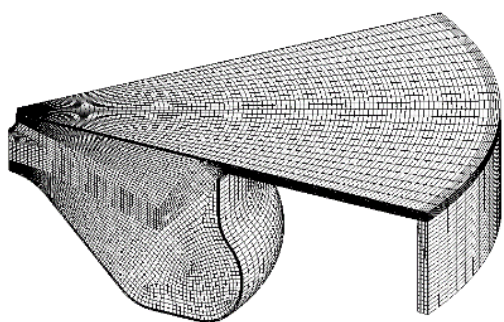

Fine Grid

TDC: 142936 Cells

BDC: 45263 Cells

Average Cell Size: $4 \mathrm{~mm}$

(a)

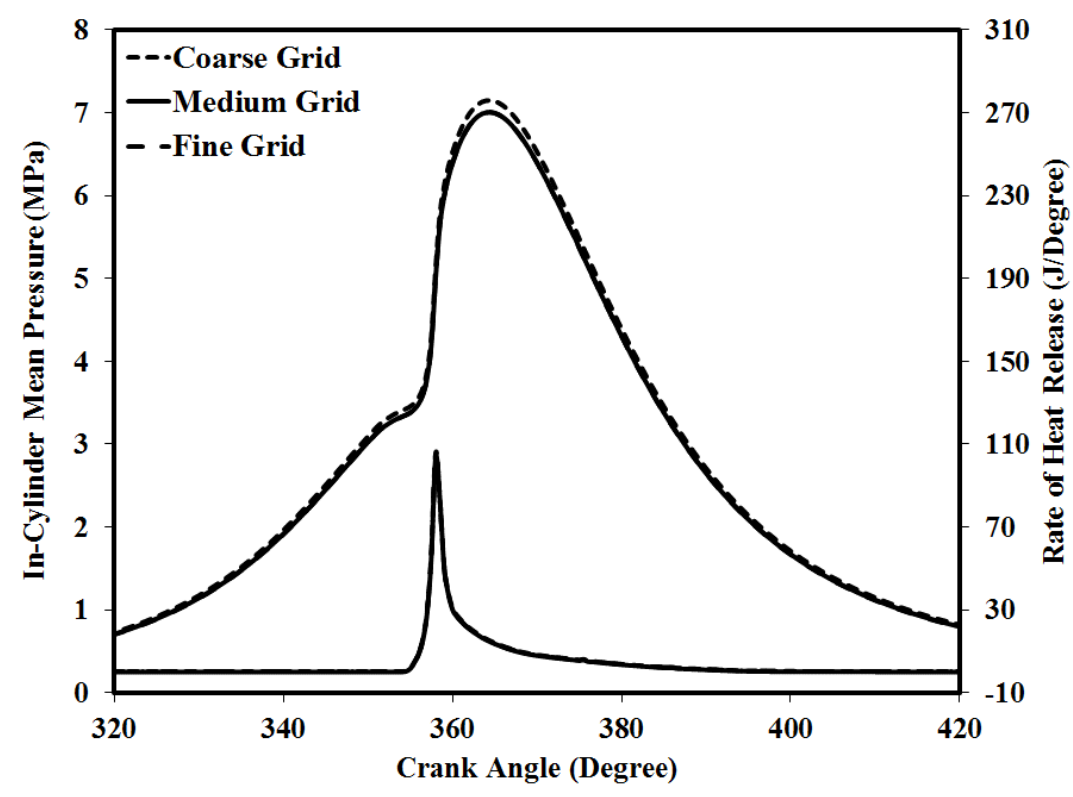

(b)

Figure 1. Computational grids at TDC and their effects on in-cylinder mean pressure and rate of heat release trends

To simulate the injection system with high degree of atomization, KH-RT break-up model used which described in ref. [37] for the primary and secondary atomization modeling of the resulting droplets. In this model Kelvin-Helmholtz (KH) surface waves and Rayleigh-Taylor (RT) disturbances should be in continuous competition of breaking up the droplets. The KH mechanism is favored by high relative velocities and high ambient density. The RT mechanism is driven by the rapid deceleration of the droplets causing the growth of surface waves at the droplet stagnation point. Table 1 shows the settings for KHRT breakup model parameters used for all simulations. 
Table 1 - Parameter settings for KHRT breakup model

\begin{tabular}{lr}
\hline Model constants & Value \\
\hline KH-WAVE model constant to adjust stable droplet radius (C1) & 0.61 \\
KH-WAVE model constant to adjust break-up time (C2) & 10 \\
Type Constant to adjust break-up length (C3) & 10 \\
RT model constant to adjust wave length (C4) & 5.33 \\
RT model constant to adjust break-up time (C5) & 1 \\
Constant for child droplet parcel number adjustment (C6) & 0.3 \\
Constant for child droplet parcel mass adjustment (C7) & 0.05 \\
Constant to adjust droplet normal velocity (C8) & 0.188 \\
\hline
\end{tabular}

Also, the Nordin model [38] was used to take parcels collision into account. The Nordin model is an improvement of the O'Rourke approach, which overcomes the grid dependency. According to Nordin's model, a collision between two parcels occurs if their trajectories intersect and the intersection point is reached at the same time and within the spray integration step [36]. The Dukowicz model was applied for treating the heat-up and evaporation of the droplets, which is described in ref. [39]. This model assumes a uniform droplet temperature. In addition, the rate of droplet temperature change is determined by the heat balance, which states that the heat convection from the gas to the droplet either heats up the droplet or supplies heat for vaporization. Table 2 shows the settings for Dukowicz evaporation model parameters used for all simulations.

Table 2 - Parameter settings for Dukowicz evaporation model

\begin{tabular}{|l|r|}
\hline Model constants & Value \\
\hline Heat transfer parameter (E1) & 1 \\
\hline Mass transfer parameter (E2) & 1 \\
\hline
\end{tabular}

The spray wall interaction model used in the simulations was based on the spray-wall impingement model described in ref. [40]. This model assumes that a droplet, which hits the wall is affected by rebound or reflection based on the Weber number. The Shell auto-ignition model was used for modeling of the autoignition [41]. In this generic mechanism, six generic species for hydrocarbon fuel, oxidizer, total radical pool, branching agent, intermediate species and products were involved. In addition, the important stages of auto-ignition such as initiation, propagation, branching, and termination were presented by generalized reactions, described in [41].

The k-zeta-f approach has been used to take account of turbulent effects. This model has been recently developed by Hanjalic, Popovac, and Hadziabdic [42]. The authors propose a version of an eddy viscosity 
model based on Durbin's elliptic relaxation concept. The aim of developing of the k-zeta-f model was to improve numerical stability of the $\overline{\mathrm{v}^{2}}-\mathrm{f}$ model, which has become increasingly popular as empirical damping functions are removed due to the employment of an additional velocity scale $\overline{v^{2}}$ derived by using an elliptic relaxation concept [36]. The original model introduces the wall boundary condition for the elliptic relaxation function $\mathrm{f}$ proportional to $1 / \mathrm{y}^{4}$ ( $\mathrm{y}$ is a dimensionless wall distance) making computations more sensitive on very near wall cells. Hanjalic et al. [42] used an eddy viscosity model, which solves a transport equation for the velocity scale ratio $\overline{v^{2}} / \mathrm{k}$ instead of $\overline{v^{2}}$ in order to achieve more robust wall boundary condition for f-equation which introduce new equation for $f_{w a l l}$ and it is proportional to $1 / \mathrm{y}^{2}$. In comparison with $\mathrm{k}-\varepsilon$ turbulence model, k-zeta-f model computing time is increased by up to $15 \%$ when compared with the computing time of $\mathrm{k}-\varepsilon$ model calculations. K-zeta-f model is beneficial and accurate for calculation of cells which are next to the wall. However, the cell next to the wall should reach a non-dimensional wall distance $y^{+}$of 3 as a maximum. In order to keep grid comply with this requirement, the k-zeta-f model was used in conjunction with wall functions for turbulence modeling [36]. Popovac and Hanjalic [42] used the blending formula for the quantities specified at the cell next to the wall as:

$\Phi_{\mathrm{P}}=\Phi_{\mathrm{V}} \mathrm{e}^{-\Gamma}+\Phi_{\mathrm{t}} \mathrm{e}^{-1 / \Gamma}$

Where $\mathrm{v}$ is the viscous and $\mathrm{t}$ the fully turbulent value of the variables: wall shear stress, production, and dissipation of the turbulence kinetic energy. In turbulence modeling in CFD Fire code, the k-zeta-f model is used in conjunction with the hybrid wall treatment and standard wall function for wall treatment and heat transfer wall models.

The combustion model is based on the Coherent Flame Model originally [36]. The ECFM-3Z model distinguishes between all three main regimes relevant in diesel combustion, namely auto-ignition, premixed flame and non-premixed, i.e., diffusion combustion [43, 44]. The auto-ignition pre-reactions are calculated within the premixed charge of fuel and air, with the ignition delay governed by the local temperature, pressure, fuel/air equivalence ratio and the amount of residual gas. Local auto-ignition is followed by premixed combustion in the fuel/air/residual gas mixture formed during the period between the start of injection and auto-ignition onset within the ECFM-3Z modeled according to a flame propagation process. The third regime is the one of diffusion combustion where the reaction takes place in a thin zone which separates fuel and oxidizer. In the ECFM-3Z it is assumed that the chemical time in the reaction zone is much smaller than the time needed for the diffusion process. Therefore the rate of reaction during diffusion combustion is determined entirely by the intermixing of fuel and oxidizer. This 
distinct separation of the different ignition/combustion regimes makes the ECFM-3Z model specifically applicable to conventional as well as alternative diesel combustion modes. In the conventional case, most part of the combustion can be assumed as diffusion type, in the case of recently introduced alternative concepts a significant amount of fuel is consumed within premixed combustion. Table 3 shows the settings for ECFM-3Z combustion model parameters used for all simulations.

Table 3 - Settings for combustion model

\begin{tabular}{lr}
\hline Mixing model parameter & 0.8 \\
Auto-ignition model & Formula \\
Auto-ignition model parameter & 1 \\
Chemical reaction time & 10000 seconds \\
Extinction temperature & $200 \mathrm{~K}$ \\
\hline
\end{tabular}

Extended Zeldovich-Prompt-Fuel model was used to simulate the NOx emission during compression ignition process in an HSDI diesel engine. The formation of NO depends mainly on three different processes, the thermal NO, the prompt NO and the fuel NO mechanism [36]. Most of the times in diesel engine applications the fuel NO can be neglected because there is no significant amount of nitrogen in the fuel. The two other mechanisms can contribute to the NO formation in engines, where mainly thermal NO is formed, but also some amount of prompt NO can appear. The model used for this work covers these two contributions [36]. The thermal NO reaction mechanism is described here by the widely accepted extended Zeldovich mechanism. This mechanism is based on the chemical equilibrium assumption, which means that only atomic nitrogen $(\mathrm{N})$ is needed as an additional intermediate species. Since its concentration does not depend on the chemical kinetics of combustion of the mixture, it is not necessary to follow the fuel oxidation in-depth but instead to use only the following chemical reaction steps $[36,45]$ :

$$
\begin{aligned}
& \mathrm{N}_{2}+\mathrm{O} \stackrel{\mathrm{k}_{1}}{\leftrightarrow} \mathrm{NO}+\mathrm{O} \\
& \mathrm{N}+\mathrm{OH} \stackrel{\mathrm{k}_{2}}{\leftrightarrow} \mathrm{NO}+\mathrm{H} \\
& \mathrm{N}+\mathrm{OH} \stackrel{\mathrm{k}_{3}}{\leftrightarrow} \mathrm{NO}+\mathrm{H}
\end{aligned}
$$

The above reaction mechanism is known as the extended Zeldovich mechanism that considers the effect of oxygen and hydrogen radicals on NO formation. It is important to point out that all three chemical reactions that represent the Zeldovich mechanism exhibit strong temperature dependency. Derived from 
the above equations the overall NO formation rate for the three thermal reactions can be described as follows $[36,45]$ :

$\frac{\mathrm{dC}_{\mathrm{NO}}}{\mathrm{d}_{\mathrm{t}}}=2 \mathrm{k}_{1 \mathrm{f}} \mathrm{C}_{\mathrm{O}} \mathrm{C}_{\mathrm{N}_{2}} \frac{1-\frac{\mathrm{k}_{1 \mathrm{f}} \mathrm{k}_{2 \mathrm{f}} \mathrm{C}_{\mathrm{NO}}^{2}}{\mathrm{k}_{1 \mathrm{f}} \mathrm{C}_{\mathrm{N}_{2}} \mathrm{k}_{2 \mathrm{f}} \mathrm{C}_{\mathrm{O}_{2}}}}{1+\frac{\mathrm{k}_{1 \mathrm{~b}} \mathrm{C}_{\mathrm{NO}}}{\mathrm{k}_{2 \mathrm{f}} \mathrm{C}_{\mathrm{O}_{2}}+\mathrm{k}_{3 \mathrm{f}} \mathrm{C}_{\mathrm{OH}}}}$

According to these equations, the thermal NO formation is independent of the fuel type. To solve the equations, the concentration of $\mathrm{O}$ atoms and the free radical $\mathrm{OH}$ is required which are both calculated either from empirical relations or, as in the present case, based upon the radical concentrations of the ECFM - 3Z combustion model.

Under specific operating conditions, such as alternative diesel combustion, the rate of NO generated during combustion of hydrocarbon substances can be considerably higher than that predicted by the Zeldovich mechanism. This enhanced NO formation is attributed to the presence of hydrocarbon species, which result from fuel fragmentation during the combustion process $[36,45]$. Prompt NO is formed by the reaction of atmospheric nitrogen with hydrocarbon fragments, which is subsequently oxidized to form NO. The prompt NO mechanism forms NO from nitrogen much earlier in the flame than the thermal NO mechanism, as its name suggests. The mechanism is initiated by the rapid reaction of hydrocarbon radicals with molecular nitrogen, resulting in the dissociation of the $\mathrm{N}_{2}$ and the formation of intermediates such as $\mathrm{HCN}$

$\mathrm{CH}_{\mathrm{x}}+\mathrm{N}_{2} \leftrightarrow \mathrm{HCN}+\mathrm{N}+\cdots$

Different hydrocarbon radicals have been suggested that are responsible for prompt NO in hydrocarbon flames, but the major contribution comes from $\mathrm{CH}$

$\mathrm{CH}+\mathrm{N}_{2} \leftrightarrow \mathrm{HCN}+\mathrm{N}$

The HCN and $\mathrm{N}$ then react through a series of subsequent fast reactions to form nitric oxide

$\mathrm{N}+\mathrm{O}_{2} \leftrightarrow \mathrm{NO}+\mathrm{O}$

$\mathrm{HCN}+\mathrm{OH} \leftrightarrow \mathrm{CN}+\mathrm{H}_{2} \mathrm{O}$

$\mathrm{CN}+\mathrm{O}_{2} \leftrightarrow \mathrm{NO}+\mathrm{CO}$

The model used in the present study to predict prompt NO concentration applies an overall approximate prompt reaction. A global kinetics mechanism is used to predict a rate of prompt NO, 
$\frac{\mathrm{dC}_{\mathrm{NO}}}{\mathrm{d}_{\mathrm{t}}}=\mathrm{k}_{\mathrm{pr}} \mathrm{C}_{\mathrm{O}_{2}} \mathrm{C}_{\mathrm{N}_{2}} \mathrm{C}_{\text {fuel }} \mathrm{e}^{\left(\frac{\mathrm{E}}{\mathrm{RT}}\right)}$

The rate of prompt NO formation is found to be of the first order concerning nitrogen and fuel concentration, but the oxygen reaction order a depends on experimental conditions $[36,45]$.

During (premixed combustion) and after fuel injection process, polycyclic aromatic hydrocarbons grow to form more massive structures. Polycyclic aromatic hydrocarbons which recognized as soot particles or Particulate matters, formed at the moment in which the PAHs are no longer arranged in a plane but rather represent a spatial structure [46]. The production of soot particles occurs in two main phases, soot formation, and soot oxidation. The soot formation in current study has modeled by using the Kennedy/Hiroyasu/Magnussen mechanism [36, 47]. Soot formation and oxidation process depend on the fuel composition, in-cylinder gas temperature and local fuel and oxygen concentrations. During the entire soot formation process, soot oxidation can also occur, and both molecular oxygen and the hydroxyl radical $\mathrm{OH}$ can have the critical role [46]. In the this model the processes of particle formation and surface growth are taken to be related functions of the local fuel and soot nuclei concentration and the predominating flame temperature governing the Arrhenius rate coefficient of the particle mass addition term [36];

Nucleation source:

$S_{n}=C_{n} e^{\left(\frac{-\left(f-f_{n}\right)^{2}}{\sigma_{n}^{2}}\right)}$

Surface growth source:

$S_{g}=A \cdot F\left(f, \Phi_{s}\right) \cdot p^{0.5} \cdot \exp \left(\frac{-E_{a}}{R T}\right)$

Due to the domination of the reaction with oxygen, the oxidation through $\mathrm{OH}$ can be neglected [36]. Table 4 shows the settings for soot model parameters used for all simulations.

Table 4 - Parameter settings for soot model

\begin{tabular}{lr}
\hline Formation rate parameter & 1 \\
Oxidation rate parameter & 0.5 \\
\hline
\end{tabular}

In diesel engines, the quality of air-fuel mixing process considerably influence the critical engine parameters such as combustion characteristics, emissions formation and also performance. So far, for diesel combustion development and research, there is no a measure for quantitatively describing fuel-air 
mixing quality. Although qualitative description/result of mixing quality can be used for assessing the mixing quality and for studying its influence on ignition, combustion, and emission, a quantitative description is desired for having a more accurate control to the mixing and combustion, in particular for HCCI/PCCI combustion for which a measure of charge mixing quality will be beneficial as a control medium for used in the controller to real-time control the ignition and combustion. Nandha et al. [48] firstly proposed a parameter named Degree of Heterogeneity (DOH), defined as follows, to measure the degree of heterogeneity in the mixture:

$\operatorname{DOH}(\theta)=\frac{\sqrt{\frac{\sum_{\mathrm{i}=0}^{\mathrm{N}_{\text {cells }}}\left[\left(\varphi_{\mathrm{i}}-\varphi_{0}\right)^{2} \delta \mathrm{m}_{\mathrm{i}}\right.}{\mathrm{M}}}}{\varphi_{0}}$

$\varphi_{\theta}=\frac{\sum_{\mathrm{i}=0}^{\mathrm{N}_{\mathrm{cells}}} \varphi_{\mathrm{i}} \delta \mathrm{m}_{\mathrm{i}}}{\mathrm{M}}$

$\mathrm{M}=\sum_{\mathrm{i}=0}^{\mathrm{N}_{\text {cells }}} \delta \mathrm{m}_{\mathrm{i}}$

The above definition for Degree of Heterogeneity (DOH) [49] represents the standard deviation of the equivalence ratio normalized by the overall equivalence ratio. Then following the initial investigation for applying a Homogeneity Factor (HF) by Peng et al. [50], a modified definition has been proposed for investigating the Homogeneity Factor (HF) in the current study. As the increased fuel amount in a cell comes from the decrease in fuel amount in other cells, the half of the standard deviation is used in the new definition to reflect the non-uniformity more accurately. Then a homogeneity factor (HF) is derived based on HeterF for having a more appropriate demonstration to the charge mixing quality. In this method, compared to the average equivalence ratio $\left(\varphi_{0}\right)$, the fuel difference in Cell into the average fuel amount is defined as follows:

$\frac{\varphi_{\mathrm{i}}}{\mathrm{AFR}_{\mathrm{st}}+\varphi_{\mathrm{i}}} \delta \mathrm{m}_{\mathrm{i}}-\frac{\varphi_{0}}{\mathrm{AFR}_{\mathrm{st}}+\varphi_{0}} \delta \mathrm{m}_{\mathrm{i}}=\frac{\mathrm{AFR}_{\mathrm{st}}\left(\varphi_{\mathrm{i}}-\varphi_{0}\right)}{\left(\mathrm{AFR}_{\mathrm{st}}+\varphi_{\mathrm{i}}\right)\left(\mathrm{AFR}_{\mathrm{st}}+\varphi_{0}\right)} \delta \mathrm{m}_{\mathrm{i}}$

The total fuel amount will be: 
$\frac{\varphi_{0}}{\mathrm{AFR}_{\mathrm{st}}+\varphi_{0}} \mathrm{M}$

Therefore, Heterogeneity Factor (HeterF) is:

$\operatorname{HeterF}(\theta)=\frac{\sum_{\mathrm{i}=0}^{\mathrm{N}_{\text {cell }}} \frac{\sqrt{\left(\varphi_{\mathrm{i}}-\varphi_{0}\right)^{2}}}{\mathrm{AFR}_{\mathrm{st}}+\varphi_{\mathrm{i}}}}{2 \varphi_{0} \mathrm{M}} \delta \mathrm{m}_{\mathrm{i}}$

The Homogeneity Factor (HF) is defined as follows:

$\operatorname{HF}(\theta)=(1-\operatorname{HeterF}(\theta)) \%$

Where $\mathrm{DOH}$ is degree of heterogeneity, $\varphi_{\mathrm{i}}$ is the equivalence ratio and $\delta \mathrm{m}_{\mathrm{i}}$ is the mass of the mixture in the computational cell $\mathrm{i}, \mathrm{N}_{\text {cells }}$ is the total number of computational cells, $\varphi_{0}$ is the overall average equivalence ratio of total mixture and $\mathrm{M}$ is the mass of total mixture, $\mathrm{AFR}_{\mathrm{st}}$ is the stoichiometric air-fuel ratio, HeterF is Heterogeneity Factor, and HF is Homogeneity Factor.

As indicated earlier, the mixing quality in diesel engines is very critical for controlling the ignition and pre-mixed combustion and mixing controlled combustion, consequently for energy conversion efficiency and emissions (HC, CO, NOx, and soot). Diluting the intake charge with fuel additives and also gaseous fuels such as hydrogen and nitrogen gas considerably affects the air-fuel ratio due to partially replacing the intake air oxygen with indicated gases. Change in in-cylinder oxygen concentration leads to changing the air-fuel mixing quality. So far, there is no a measure for quantitatively describing fuel-air mixing quality especially when fuel additive and gases fuel have also involved. Although qualitative description of mixing quality can be used for assessing the mixing quality and for studying its influence on ignition, combustion and emission, a quantitative description is desired for having a more accurate control to the mixing and combustion. For this reason, a modified parameter named "Homogeneity Factor (HF)" has been defined and proposed by the authors as an efficient measure in order to analyze the air-fuel mixing process and mixture quality for studying the influences of fuel additives and gaseous fuels in air-fuel mixing process.

Part of this study explores the effects of separate and simultaneous addition of hydrogen and nitrogen gas on the indicated specific energy consumption (ISEC) which is calculated using equation (13): 
$\operatorname{ISEC}\left(\frac{\mathrm{Kj}}{\mathrm{Kwh}}\right)=\frac{\mathrm{N} * 60 * \mathrm{E}_{\mathrm{tot}}}{\frac{\mathrm{n}}{2} * \mathrm{IP}}$

Where $\mathrm{N}$ is engine speed (RPM), IP is indicated power $(\mathrm{Kw}), \mathrm{n}$ is number of revolutions per cycle, and $E_{\text {tot }}$ is total energy exerted to the cylinder per cycle $(\mathrm{Kj})$ which is calculated using equation (14):

$\mathrm{E}_{\text {tot }}=\mathrm{m}_{\text {Diesel }} * \mathrm{LHV}_{\text {Diesel }}+\mathrm{m}_{\mathrm{H}_{2}} * \mathrm{LHV}_{\mathrm{H}_{2}}$

Where $\mathrm{m}_{\text {Diesel }}$ is mass of diesel fuel per cycle $(\mathrm{Kg}), \mathrm{LHV}_{\text {Diesel }}$ is lower heating value of diesel fuel $\left(\frac{\mathrm{Kj}}{\mathrm{Kg}}\right)$, $\mathrm{m}_{\mathrm{H}_{2}}$ is mass of hydrogen gas per cycle $(\mathrm{Kg})$ and $\mathrm{LHV}_{\mathrm{H}_{2}}$ is lower heating value of hydrogen gas $\left(\frac{\mathrm{Kj}}{\mathrm{Kg}}\right)$.

\section{Engine Specifications, Experimental Setup and Models Validation}

The engine used for these series of simulations is a high-speed direct injection HSDI diesel engine. The FORD motor company built the engine and known as the Puma engine. The engine block is based on the 2.0L Ford Duratorq engines. The cylinder head is a production Ford Zetec head and is equipped with double overhead cams. The production model of the Puma engine had different bowl design and a compression ratio of 19:1 but the engine that is used for experimental studies which are located at the Brunel University, has a lower compression ratio of 18.2 due to the larger bowl volume. A full list of the engine specifications is in Table 5 [51].

Table 5 - Engine Specifications

\begin{tabular}{lr}
\hline Engine type & Ford Puma High-Speed diesel engine \\
\hline Number of Cylinders & 4 \\
Bore x Stroke & $86 \mathrm{~mm} \times$ \\
Compression ratio & $186.2: 1$ \\
Displacement volume & $1998.23 \mathrm{cc}$ \\
Connecting rod length & $155 \mathrm{~mm}$ \\
\hline
\end{tabular}




\begin{tabular}{lr}
\hline Engine speed & $1500 \mathrm{rpm}$ \\
IMAP & $0.1 \mathrm{MPa}$ \\
IMAT & $353 \mathrm{~K}$ \\
Coolant temperature & $350 \mathrm{~K}$ \\
\hline
\end{tabular}

Figure 2 shows the piston template variables. The baseline piston geometry used in this study is based on Ref. [51]. The compression ratio of the engine is 18.2:1 and nominal bowl volume is 21.7 cc. Table 6 shows the parameters for piston bowl.

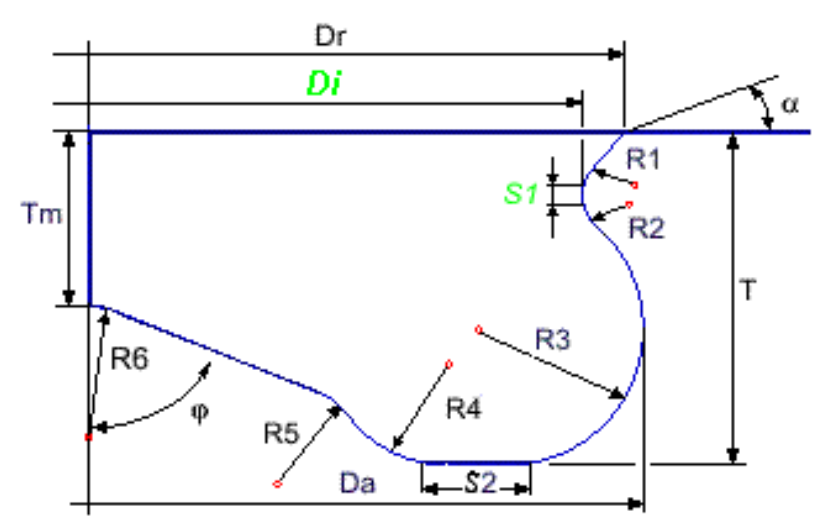

Figure2. Piston template

Table 6 - Piston Geometry Parameters [51]

\begin{tabular}{lr}
\hline Central bowl in piston & \\
\hline Clearance gap (TDC) & $0.86 \mathrm{~mm}$ \\
Bowl diameter (Dr) & $45.4 \mathrm{~mm}$ \\
Outer bowl diameter (Da) & $48.1 \mathrm{~mm}$ \\
Bowl depth (T) & $14.8 \mathrm{~mm}$ \\
Bowl center depth (Tm) & $4.8 \mathrm{~mm}$ \\
Piston bowl floor length (S2) & $4.6 \mathrm{~mm}$ \\
R1 (Radius) & $1 \mathrm{~mm}$ \\
R2 (Radius) & $3.8 \mathrm{~mm}$ \\
Bowl radius (R3) & $4.7 \mathrm{~mm}$ \\
R4 (Radius) & $4.7 \mathrm{~mm}$ \\
R5 (Radius) & $1 \mathrm{~mm}$ \\
R6 (Radius) & $5.9 \mathrm{~mm}$ \\
Alpha (Angle) & $0.1 \mathrm{degree}$ \\
\hline
\end{tabular}


The base high-speed diesel engine used in the present study is equipped with a high-pressure $2^{\text {nd }}$ generation Delphi common-rail injection system. The engine has a centrally mounted injector, and the maximum achievable pressure in the rail is 1600 bar, but it can inject fuel at low pressure. The fuel injection system specifications are in Table 7 [51].

Table 7 - Fuel Injection System Specifications

\begin{tabular}{lr}
\hline Injector type & $\begin{array}{r}\text { Common rail-VCO-760 } \\
\text { cc/min@ @ 100 bar }\end{array}$ \\
\hline Injection pressure & $1200 \mathrm{bar}$ \\
Number of nozzle holes & 6 \\
Nozzle hole diameter & $0.154 \mathrm{~mm}$ \\
Injector cone angle & $154 \mathrm{Deg}$ \\
Fuel temperature & $343 \mathrm{~K}$ \\
\hline
\end{tabular}

The diesel fuel which used during all simulations is Ultra Low Sulphur Diesel EN-590 commercially available 52.1 CN diesel. During all simulations, fuel injection pressure was constant. The fuel delivery system was an electronically controlled, common rail fuel injection system. The diesel fuel and hydrogen gas specifications are presented in Table 8 and Table 9 [51].

Table 8 - Diesel Fuel Specifications

\begin{tabular}{lcr}
\hline & Method & Value \\
\hline Flash point $(\mathrm{degC})$ & IP 34 & 71 \\
Carbon residue on $10 \%$ & IP 14 & 0.2 \\
Ash content $\%(\mathrm{~m} / \mathrm{m})$ & IP 4 & Lower than 0.005 \\
Water content $(\mathrm{mg} / \mathrm{Kg})$ & ASTM D1744 & 61 \\
Particulates $(\mathrm{mg} / \mathrm{kg})$ & DIN 51419 & 13 \\
Oxidation stability $\left(\mathrm{g} / \mathrm{m}^{3}\right)$ & ASTM D 2274 & 14 \\
Sulphur, $\%(\mathrm{~m} / \mathrm{m})$ & IP 336 & 0.19 \\
\hline
\end{tabular}




\begin{tabular}{lcr}
\hline Lower calorific value $(\mathrm{MJ} / \mathrm{Kg})$ & Ref. [42] & 52.1 \\
Density @ 15 degC $\left(\mathrm{Kg} / \mathrm{m}^{3}\right)$ & ASTM D4052 & 853.8 \\
Cetane number & ASTM D613 & 52.1 \\
Cetane index & ISO 4264 & 47.3 \\
Carbon \% (m/m) & ASTM D5291 & 86.2 \\
Hydrogen \% (V/V) & ASTM D5291 & 13.4 \\
\hline
\end{tabular}

Table 9 - Hydrogen Gas Specifications

\begin{tabular}{lr}
\hline Density $\left(\mathrm{Kg} / \mathrm{m}^{3}\right)$ & 0.0824 \\
Flammability limits (\% vol. in air) & $4-75$ \\
Flammability limits $(\varphi)$ & $0.1-7.1$ \\
Auto-ignition temperature in air $(\mathrm{K})$ & 858 \\
Minimum ignition energy $[\varphi=1](\mathrm{MJ})$ & 0.02 \\
Flame velocity $[\varphi=1](\mathrm{m} / \mathrm{s})$ & 1.85 \\
Adiabatic flame temperature $[\varphi=1](\mathrm{K})$ & 2480 \\
Lower calorific value $(\mathrm{MJ} / \mathrm{Kg})$ & 119.7 \\
\hline
\end{tabular}

Figure 3 shows the schematic view of the engine test bed [51]. As can be seen, Nitrogen and hydrogen gases are stored separately in the reservoirs specified in the figure. Gases enter the combustion chamber through the air inlet and outlet through the intercooler. According to the figure, diesel fuel will also be sprayed into the combustion chamber through a high-pressure spray system.

Considering that the present study was carried out using mathematical models to simulate the dieselhydrogen combustion process, and also the computational grid does not have intake valves and or exhaust valves, so it is assumed that the nitrogen and or hydrogen gases are available at the beginning of the IVC event inside the combustion chamber. The ratio of hydrogen and or nitrogen gas addition can be defined as the mass fraction of $\mathrm{H}_{2} / \mathrm{N}_{2}$ in $\mathrm{H}_{2}$-air or $\mathrm{N}_{2}$-air at IVC. In this paper, it is assumed that air into the cylinder was composed of $\mathrm{O}_{2}$ and $\mathrm{N}_{2}$ and also their volume fraction was $20.9 \%$ and $79.1 \%$ respectively. The mass fraction of hydrogen and nitrogen gas in the air can be concluded by Equation (23) and (24) respectively: 


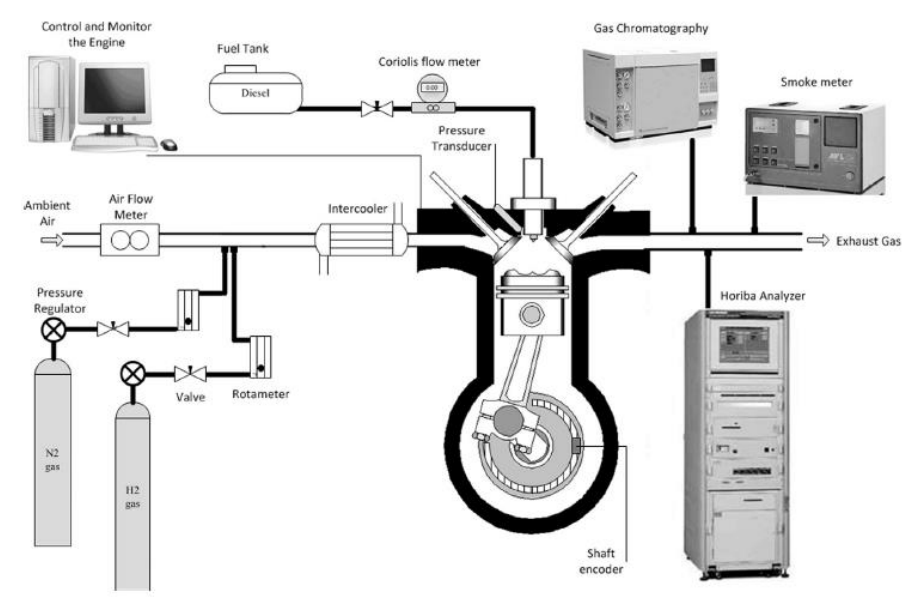

Figure 3. Schematic view of the engine test bed [51]

$\mathrm{H}_{2}$ (Mass fraction $)=\frac{\rho_{\mathrm{H}_{2}} \cdot \mathrm{V} \cdot \alpha}{\rho_{\mathrm{H}_{2}} \cdot \mathrm{V} \cdot \alpha+0.209 \cdot \rho_{\mathrm{O}_{2}} \cdot(1-\alpha) \cdot \mathrm{V}+0.791 \cdot \rho_{\mathrm{N}_{2}} \cdot(1-\alpha) \cdot \mathrm{V}}$

$\mathrm{N}_{2}($ Mass fraction $)=\frac{\rho_{\mathrm{N}_{2}} \cdot \mathrm{V} \cdot \beta}{\rho_{\mathrm{N}_{2}} \cdot \mathrm{V} \cdot \beta+0.209 \cdot \rho_{\mathrm{O}_{2}} \cdot(1-\beta) \cdot \mathrm{V}+0.791 \cdot \rho_{\mathrm{N}_{2}} \cdot(1-\beta) \cdot \mathrm{V}}$

Where $\rho_{\mathrm{H}_{2}}, \rho_{\mathrm{N}_{2}}$ and $\rho_{\mathrm{O}_{2}}$ are the density of $\mathrm{H}_{2}, \mathrm{~N}_{2}$, and $\mathrm{O}_{2}$ respectively. $\mathrm{V}$ is the cylinder volume when the piston is located at the IVC position and $\alpha$, and $\beta$ are the percentages of $\mathrm{H}_{2}$ and $\mathrm{N}_{2}$ addition.

All validations have been performed using experimental data on the four cylinders high-speed diesel engine with the specifications as listed in Table 5. To measure the in-cylinder pressure of the engine a Kistler 6125A piezoelectric pressure transducer with a range of 0-250 bar which fits into the first cylinder glow plug bore was used. In the case of amplifying the signals, a Kistler 5001 charge amplifier coupled with shaft encoder signal was used and all data recorded by the LabView software. It should be noted that the in-cylinder pressure was averaged from 100 consecutive cycles. Table 10 shows the operating conditions for the high-speed direct injection diesel engine for four different experimental studied cases.

Table 10 - Operating conditions for HSDI diesel engine

\begin{tabular}{lcccc}
\hline Parameters & Case A & Case B & Case C & Case D \\
\hline Speed (RPM) & \multicolumn{3}{c}{1500} \\
BMEP (bar) & - & $4 \% \mathrm{H}_{2}$ & $4 \% \mathrm{~N}_{2}$ & $6 \% \mathrm{H}_{2}+6 \% \mathrm{~N}_{2}$ \\
Gas addition (v/v)\% total intake charge & 594 & 546.48 & 594 & 522.72 \\
Diesel flow rate $(\mathrm{g} / \mathrm{h})$ & & & \\
\hline
\end{tabular}




\begin{tabular}{lcccc}
\hline Hydrogen gas flow rate $(\mathrm{g} / \mathrm{h})$ & - & $5.9 \mathrm{e}-5$ & - & $8.8 \mathrm{e}-5$ \\
Nitrogen gas flow rate $(\mathrm{g} / \mathrm{h})$ & - & - & $8.1 \mathrm{e}-4$ & $1.2 \mathrm{e}-3$ \\
Oxygen flow rate $(\mathrm{g} / \mathrm{h})$ & 23.256 & 22.325 & 22.325 & 20.465 \\
Common rail Pressure (bar) & 1200 & 1200 & 1200 & 1200 \\
DI Timing (CA BTDC) & 9 & 9 & 9 & 6 \\
\hline
\end{tabular}

Figure 4 reported the measured and calculated mean in-cylinder pressure and rate of heat release for neat diesel combustion (NDC), $4 \% \mathrm{H}_{2}$ addition, $4 \% \mathrm{~N}_{2}$ addition and simultaneous addition of $6 \%$ nitrogen and $6 \%$ hydrogen to the combustion chamber.

As illustrated in Figure 4, the trends predicted by the model is reasonably close to experimental results, although there are still some differences as can be seen in figures. These discrepancies could be related to experimental uncertainties in input parameters to the computations such as the precise injection duration, start of injection timing and gas temperature at IVC. Table 11 shows the initial boundary conditions used for all simulations. With regard to the unideal agreement between experimental and simulating results of Case D, it might be because the simulation model did not consider adequate gas leaking through the piston ring gaps. Then the in-cylinder pressure at the compression end became higher than the actual (experimental) condition and it results in an early ignition. The more accurate model should be developed in the following study in order to achieve more precise effects on combustion process and emissions.

Table 11 - Initial boundary conditions

\begin{tabular}{|l|r|}
\hline In-cylinder pressure @ IVC event & $0.1 \mathrm{MPa}$ \\
\hline In-cylinder Temperature @ IVC event & $383 \mathrm{~K}$ \\
\hline Swirl ratio @ IVC event & $1.1(-)$ \\
\hline Piston Top Temperature & $560 \mathrm{~K}$ \\
\hline Cylinder Head Temperature & $560 \mathrm{~K}$ \\
\hline Cylinder Wall Temperature & $420 \mathrm{~K}$ \\
\hline
\end{tabular}

Regarding the emissions measuring, Horiba Mexa 7170DEGR, AVL 415S smoke meter and a gas chromatograph HP 5890 equipped with a thermal conductivity detector was used to detail exhaust gas analyzing. Table 12 reported the comparison between measured and calculated engine-out NOx, soot and $\mathrm{CO}$ emissions. 

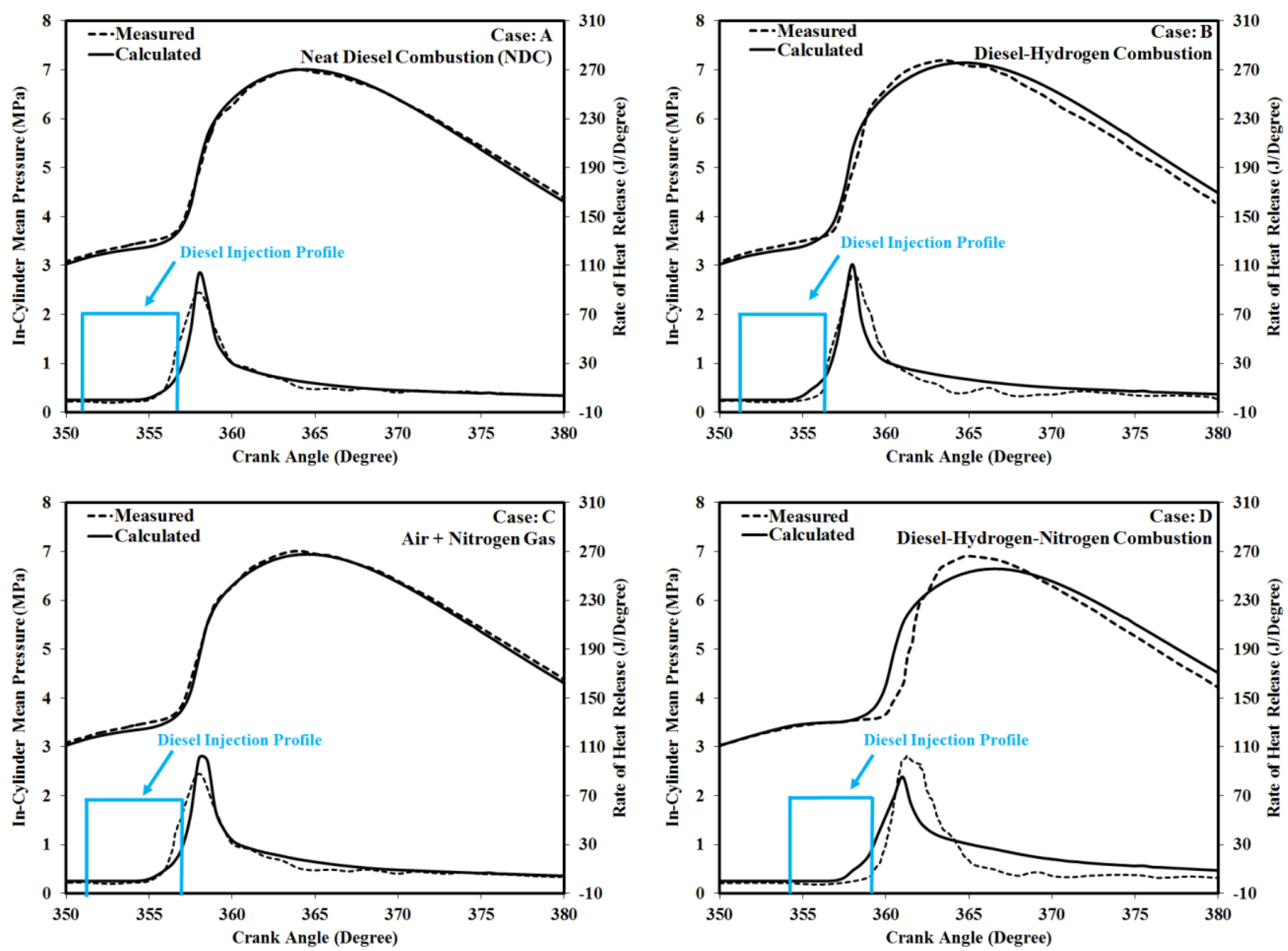

Figure 4. Validation of in-cylinder pressure and ROHR for four different studied cases

Table 12 - Measured and Calculated engine-out emissions at 1500 RPM and 5 bar load [51]

\begin{tabular}{lccc}
\hline Engine operation condition & $\begin{array}{c}\mathrm{NOx} \\
\text { measured/calculated } \\
\text { g/kg. fuel }\end{array}$ & $\begin{array}{c}\text { Soot } \\
\text { measured/calculated } \\
\text { g/kg. fuel }\end{array}$ & $\begin{array}{c}\mathrm{CO} \\
\text { measured/calculated } \\
\mathrm{g} / \mathrm{kg} \text {. fuel }\end{array}$ \\
\hline Neat diesel & $9.5 / 9.7$ & $0.75 / 0.73$ & $1.57 / 1.53$ \\
$4 \% \mathrm{H}_{2}+$ diesel & $12.1 / 12.3$ & $0.25 / 0.23$ & $1.25 / 1.21$ \\
$4 \% \mathrm{~N}_{2}+$ diesel & $7.13 / 7.2$ & $0.95 / 0.94$ & $2.0 / 1.97$ \\
$6 \% \mathrm{H}_{2}+6 \% \mathrm{~N}_{2}+$ diesel & $9.45 / 9.3$ & $0.08 / 0.085$ & $1.89 / 1.9$ \\
\hline
\end{tabular}

As can be seen in Table 12, the amount of pollutant emissions were well calculated by the model. It is evident from Table 6 that predicted trends are relatively similar to the experimental values. In particular, they capture the trends of increased NOx and reduced soot emission simultaneously by addition of 
hydrogen gas to the combustion chamber and a decrease in NOx level and increased soot emission by induction of nitrogen respectively [51].

It should be noted that all the experimental cases except for Case D (simultaneous addition of hydrogen and nitrogen gases) have the same DI timing. For this purpose, according to the Figure 4 and Table 12, and to succeed in simulating the four experimental cases, to have a consistent and more precise trend in the present study in order to examine the influences on the emissions formation, engine performance and the combustion characteristics, for the simultaneous addition of hydrogen and nitrogen gases (Case D), the timing of diesel direct injection timing was set to 9 CA BTDC.

\section{Modeling Methodology}

The main objective of this study is to investigate the effects of separate and simultaneous addition of hydrogen and nitrogen gases on the combustion process of a high-speed direct injection diesel engine. Considering the success achieved with validation, 25 research strategies have been taken into account that their effects on combustion characteristics (mean in-cylinder temperature, the rate of heat release, homogeneity factor, and the length of spray penetration), engine performance (indicated specific energy consumption and indicated power of the engine), as well as engine exhaust emissions (Carbon monoxide, soot particles, and nitrogen oxides) have been investigated. Comparing with experimental research [51], in this numerical study the effects of $\mathrm{H}_{2}$ and $\mathrm{N}_{2}$ addition on energy consumption has been discussed. In addition, Homogeneity Factor was used for better understanding and measuring the air-fuel mixing quality and also mixing process following the addition of gaseous fuel $\left(\mathrm{H}_{2}\right)$ and fuel additive $\left(\mathrm{N}_{2}\right)$ which there is no such device which can measure this parameter in real-time during operation.

This study is divided into two parts. The first part deals with the influence of adding nitrogen and hydrogen gases in the range of 2 to $8 \% \mathrm{v} / \mathrm{v}$ of total intake charge to the combustion chamber with $2 \%$ steps. In the second section, the simultaneous effects of adding nitrogen and hydrogen gases were investigated. The percentage of hydrogen gas (2, 4, 6 and 8 percent) was kept constant, and the volume of nitrogen in the range of 2 to 8 percent with $2 \%$ steps has been increased. It is worth mentioning that in this study, every $2 \%$ hydrogen gas addition has been replaced with $4 \%$ of the total mass of diesel fuel per cycle. Table 13 indicates the calculation process. Furthermore, due to the low fuel mass per cycle and the prevention of the incomplete combustion and increased emissions such as soot and CO produced from the incomplete combustion of diesel fuel in a high-speed direct injection diesel engine, the range of 2 to $8 \%$ $\mathrm{v} / \mathrm{v}$ of total intake charge for gas addition was chosen for this study. In general, the results of this study 
have been gathered in three sections: combustion characteristics, exhaust emissions and engine performance, which have been discussed in detail in the form of charts and figures.

Table 13 - Calculation process for hydrogen addition and diesel injection

\begin{tabular}{ccc}
\hline $\mathrm{H}_{2}$ addition & $\mathrm{N}_{2}$ addition & Diesel injection per cycle \\
{$[\%$ Vol.] } & {$[\%$ Vol. $]$} & {$[\mathrm{mg}]$} \\
\hline 0 (Neat diesel combustion) & & 13.2 \\
2 & & 12.6 \\
4 & $0,2,4,6$, and $8 \%$ & 12.1 \\
6 & & 11.6 \\
8 & & 11.0 \\
\hline
\end{tabular}

\section{Results and Discussion}

\subsection{Effects of $\mathrm{H}_{2}$ and $\mathrm{N}_{2}$ addition on combustion characteristics}

Figure 5(a), (b), (c), (d) and (e) showed the separate and simultaneous effects of hydrogen and nitrogen gas addition on the homogeneity of the air-fuel mixing process, in-cylinder mean temperature, the rate of heat release and the length of spray penetration respectively. As can be seen in Figure 5(a), increasing the percentage of nitrogen gas have increased the peak of homogeneity factor. The addition of nitrogen gas to the combustion chamber has led to a lower oxygen content in the combustion chamber of air and fuel and also resulting in a decrease in the air-fuel ratio. Figure 5(b) reported the effects of hydrogen gas addition on the air-fuel mixing process of diesel-hydrogen combustion. As can be seen, increasing the percentage of hydrogen gas addition have decreased the peak of homogeneity factor. Replacing the part of the diesel fuel with the specific amount of hydrogen gas leads to increase the air-fuel ratio, and as a result, the peak of homogeneity factor has decreased.

Figure 5(c) reported the influence of the simultaneous addition of hydrogen and nitrogen gases on the airfuel mixing process of diesel-hydrogen combustion. As illustrated in Figure 5(c), simultaneous addition of hydrogen and nitrogen gases lead to decrease the peak of homogeneity factor. As mentioned earlier, due to replacing the part of diesel fuel with a specific amount of hydrogen gas, the air-fuel ratio has increased, and following that, the peak of homogeneity factor has decreased. Although the addition of nitrogen gas reduces the air-fuel ratio and increases the maximum point of homogeneity, addition of hydrogen gas simultaneous with replacing the part of diesel fuel per cycle with a certain amount of hydrogen gas have increased the air-fuel ratio and have reduced the peak of homogeneity factor. It can be 
concluded that the addition of hydrogen gas in comparison with nitrogen has a greater impact on the airfuel mixing process inside the combustion chamber.

Figure 5(d) shows effects of separate and simultaneous addition of hydrogen and nitrogen gases on the incylinder mean temperature and the rate of heat release. As can be seen, the addition of nitrogen gas leads to decrease both peak of in-cylinder temperature and the rate of heat release. By replacing part of the intake air with the nitrogen gas, less oxygen is introduced into the combustion chamber during the intake stroke. Following that, the air-fuel ratio decreases and also, the process of diesel fuel oxidation is weakened, and as can be seen in Figure 5(d), the in-cylinder mean temperature and the maximum point of the heat release rate have decreased.

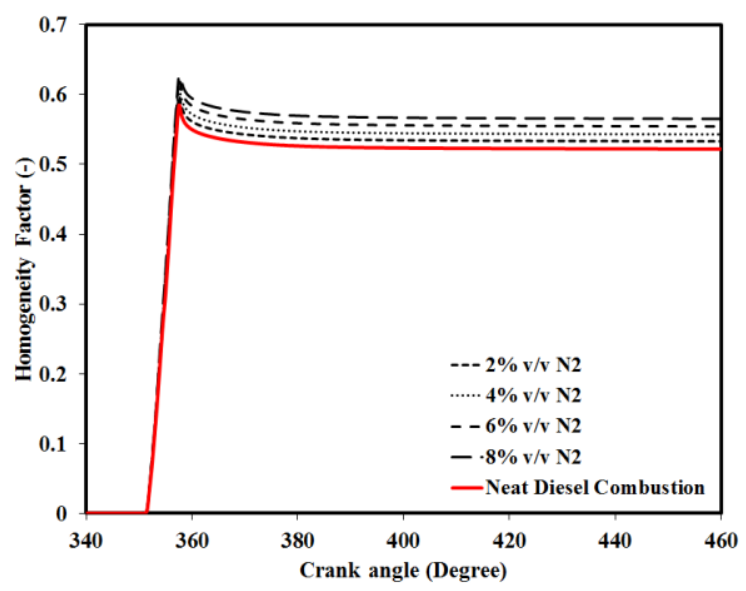

(a)

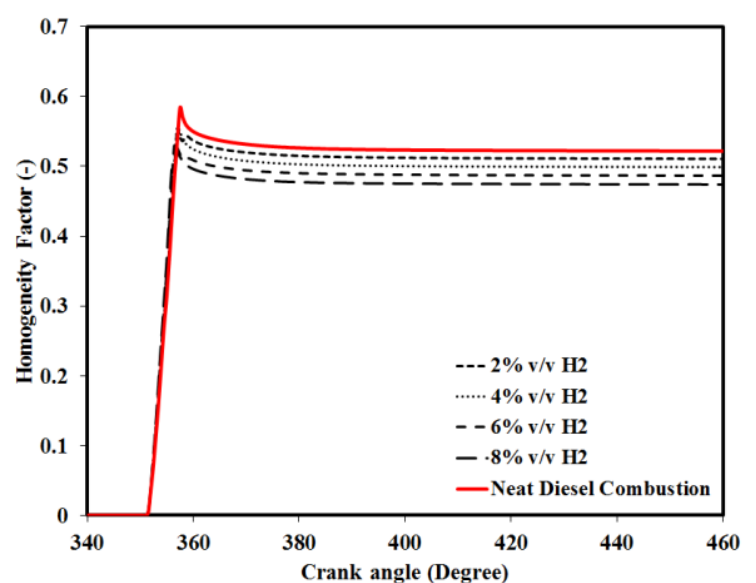

(b)

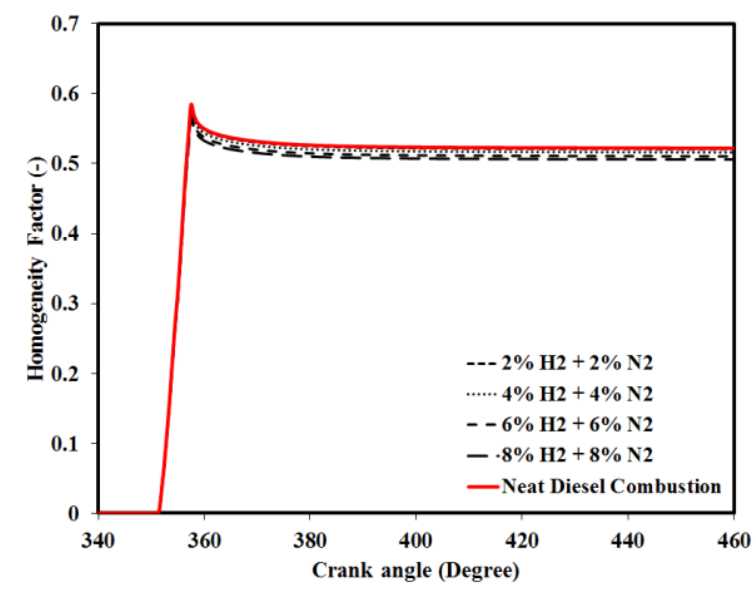

(c) 


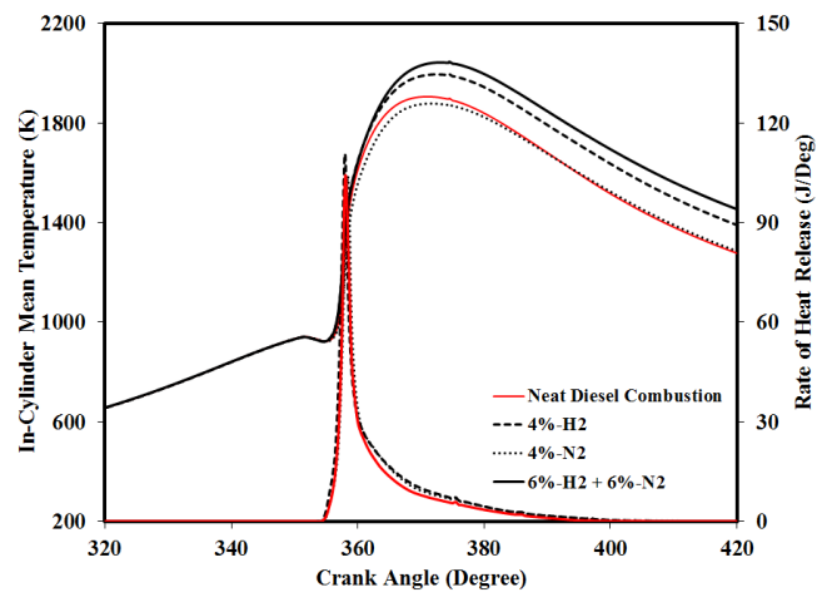

(d)

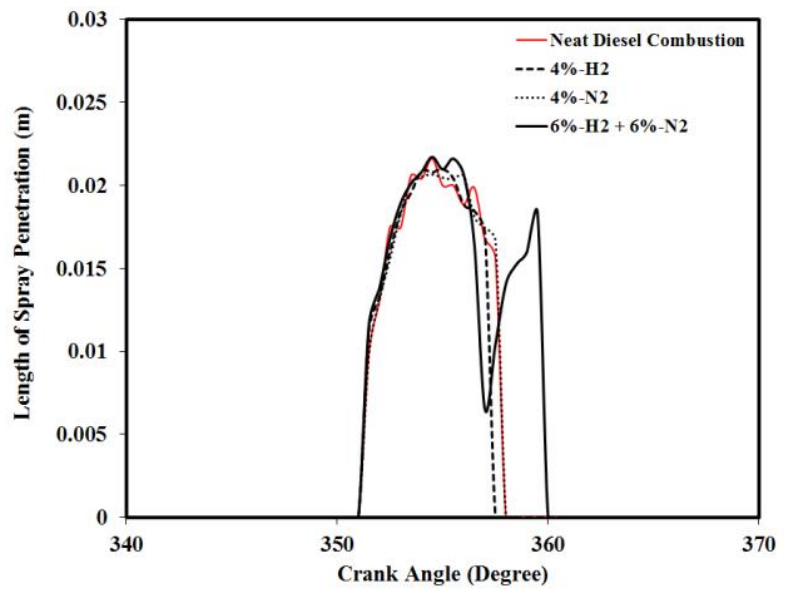

(e)

Figure 5. Effects of hydrogen and nitrogen gas addition on the combustion characteristics

As illustrated in Figure 5(d), the addition of the hydrogen gas has increased the mean in-cylinder temperature and the maximum point of the heat release rate. Also, the simultaneous addition of hydrogen and nitrogen gases have increased these two combustion characteristics. Due to the high heating value of hydrogen gas, adding this type of gas into the cylinder and participation in the combustion process of diesel fuel has increased the mean in-cylinder temperature as well as the peak of heat release rate in compared with neat diesel combustion. Figure 5(e) has reported the effects of separate and simultaneous nitrogen and hydrogen gas addition on the Length of Spray Penetration (LSP). As indicated to Figure 4(e), adding $4 \%$ hydrogen gas v/v of total intake charge has reduced the LSP.

According to the strategy adopted in the present study of replacing part of diesel fuel with a specific amount of hydrogen gas in each operating cycle has led to a lower amount of diesel fuel to be injected and as a result, the LSP has been decreased. The addition of nitrogen gas inside the combustion chamber has also reduced the LSP compared to neat diesel combustion. It can be concluded that the addition of nitrogen gas into the cylinder has reduced the flow rate of the sprayed fuel particles. In compared with clean diesel combustion, simultaneous addition of hydrogen and nitrogen gases did not have a much considerable effect on the LSP. By comparing the two modes of adding nitrogen and hydrogen gas separately and simultaneously, it can be concluded that by replacing about $12 \%$ of the oxygen present in the cylinder with gases with a relatively low density compared with oxygen, the relative pressure of the region close to the injection system and also inside the combustion chamber has been reduced, resulting in an increase in the LSP. 
Figure 6 shows the equivalence ratio contours for the separate and simultaneous addition of hydrogen and nitrogen gases in compared with neat diesel combustion at $410 \mathrm{CA}$. According to Figure 6, the addition of nitrogen gas to the cylinder in comparison with pure diesel combustion has led to increasingly large, airfuel rich regions inside the combustion chamber and also the air-fuel ratio has decreased. Also, the introduction of a separate hydrogen gas or simultaneously with nitrogen reduces the air-fuel large, rich regions. Based on the strategy adopted in the present study, replacing a part of diesel fuel with a certain amount of $\mathrm{H}_{2}$ gas per each operating cycle, adding a separate hydrogen gas or simultaneously with nitrogen would increase the air-fuel ratio. As previously mentioned, the addition of hydrogen gas, either individually or simultaneously with nitrogen gas, reduces the maximum point of homogeneity factor (HF) and the separate addition of nitrogen gas into the combustion chamber increases the peak of the HF. It can be concluded that a homogeneity factor is an appropriate tool for predicting and investigating the air-fuel combustion process that by increasing the maximum point of HF the air-fuel rich regions increase and vice versa.

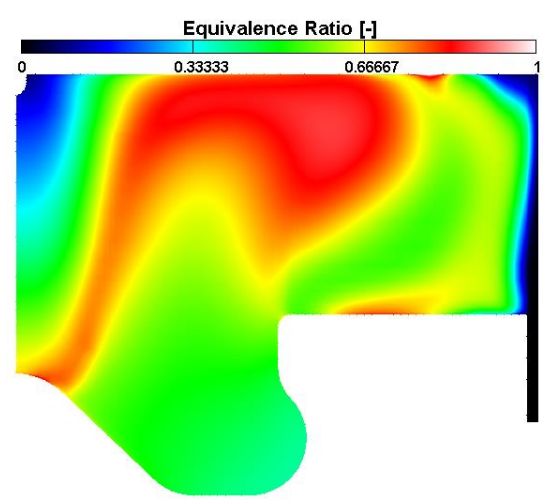

Neat Diesel Combustion

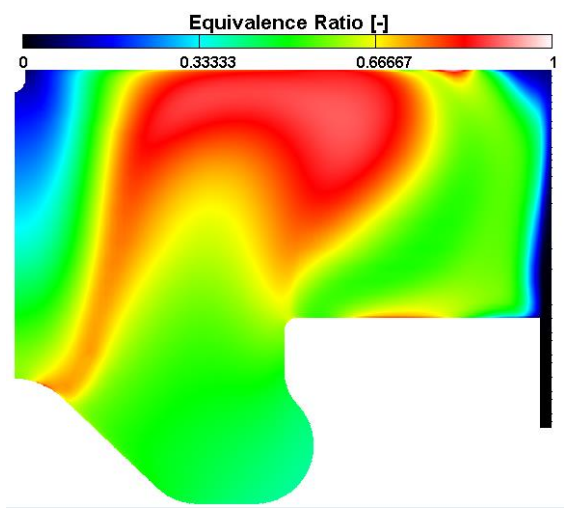

$4 \% \mathrm{~N}_{2}$ gas addition

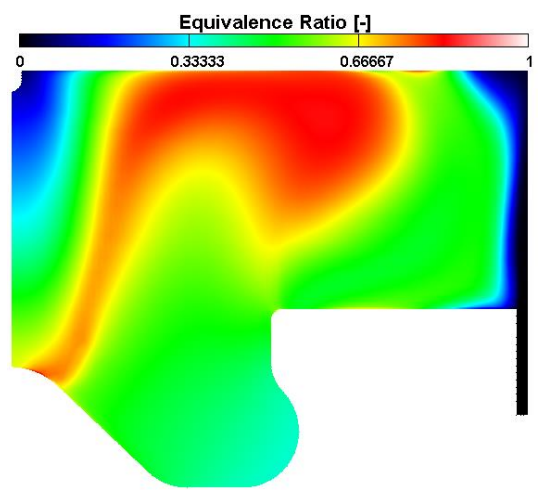

$4 \% \mathrm{H}_{2}$ gas addition

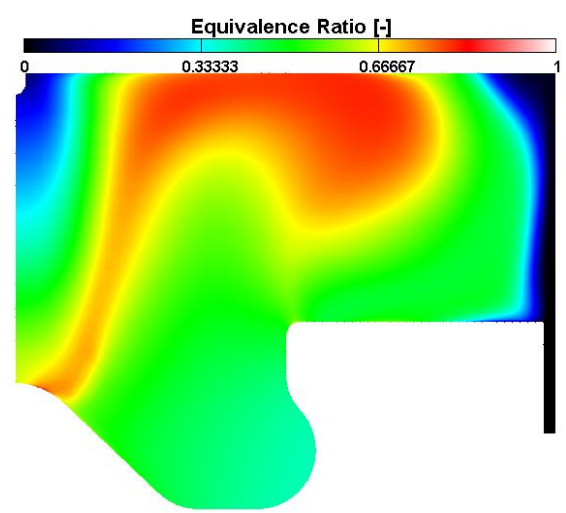

$6 \% \mathrm{H}_{2}+6 \% \mathrm{~N}_{2}$ gas addition

Figure 6. Effects of separate and simultaneous addition of $\mathrm{H}_{2}$ and $\mathrm{N}_{2}$ on 
Equivalence ratio in comparison with neat diesel combustion at $410 \mathrm{CA}$

\subsection{Effects of $\mathrm{H}_{2}$ and $\mathrm{N}_{2}$ addition on emissions formation}

Figure 7(a) has reported the effects of separate addition of nitrogen and hydrogen gases on NOx emissions formation in comparison with Neat Diesel Combustion (NDC) operation. As can be seen, the addition of hydrogen gas has increased the NOx emissions, and a single addition of nitrogen gas has decreased the NOx emissions. Addition of nitrogen gas inside the cylinder has reduced the amount of oxygen entering the combustion chamber due to the replacement the part of the intake charge with nitrogen gas and, as previously indicated, the maximum points of in-cylinder mean temperature, and the rate of heat release have been decreased. The addition of nitrogen gas has reduced the temperature, and the amount of oxygen level in the cylinder, which are important factors in the process of formation and oxidation of nitrogen oxides emissions, and thus the process of NOx formation has been weakened. As reported in Figure 7(a), the addition of $8 \%$ v/v of total intake charge with $\mathrm{N}_{2}$ gas in comparison with NDC operation has significantly reduced the NOx emissions by nearly $51 \%$. Also, the introduction of $\mathrm{N}_{2}$ gas into the combustion chamber, the Air-Fuel Ratio (AFR) has decreased, and the peak of HF has increased. It can be concluded that adding $\mathrm{N}_{2}$ gas has increased the high rich regions of air-fuel mixtures and leads to weakening the oxidation process of diesel fuel distributed in the combustion chamber and as a result, NOx emissions have been decreased.

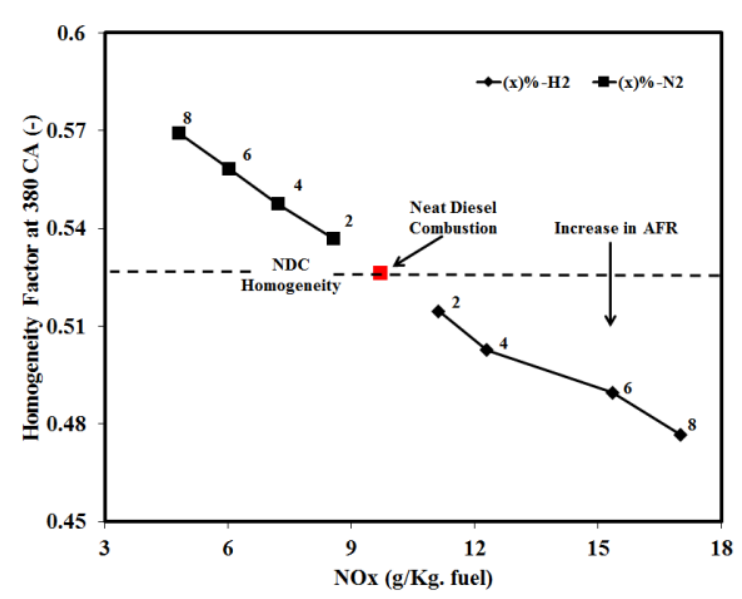

(a)

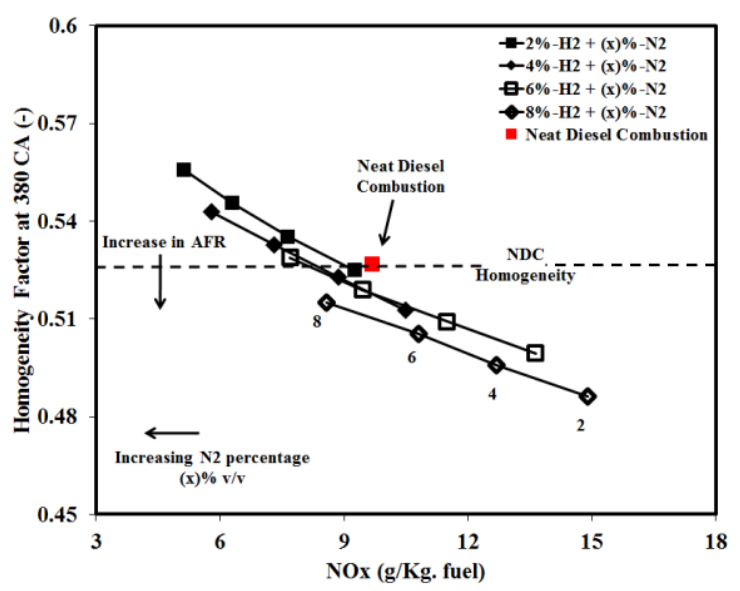

(b)

Figure 7. NOx versus $\mathrm{HF}$ at $380 \mathrm{CA}$, The effects of separate and simultaneous addition of nitrogen and hydrogen gases on NOx emissions formation in comparison with NDC operation 
According to Figure 7(a), separate addition of hydrogen gas has increased the NOx emissions. Hydrogen gas participation in the air-fuel combustion process has significantly increased the resulting combustion temperature. Furthermore, as noted earlier, replacing a part of diesel fuel with a certain amount of hydrogen gas has increased the AFR. Increasing the in-cylinder mean temperature and AFR of the combustion process has caused, firstly, higher oxygen content to form the nitrogen oxides, and secondly, the increase in temperature has increased the rate of NOx formation. As shown in Figure 7(a), the addition of $8 \%$ of total intake charge with $\mathrm{H}_{2}$ gas to the cylinder has caused the NOx emissions increase by about $75 \%$ in comparison with NDC operation. It can be concluded that by adding hydrogen gas into the combustion chamber, the rich air-fuel regions has decreased, and the air-fuel oxidation process due to the high-temperature combustion and increased AFR has been improved, thereby, NOx emissions have increased.

Figure 7(b) has reported the effects of simultaneous hydrogen and nitrogen gas addition on NOx emissions formation. As can be seen, simultaneous addition of hydrogen gas ( $8 \%$ of total intake charge) and nitrogen gas ( $8 \%$ of total intake charge) has decreased the nitrogen oxides by nearly $11.5 \%$ in comparison with NDC operation. It can be concluded that simultaneous addition of hydrogen and nitrogen gas is effective mean to improving the overall combustion process by increasing the combustion temperature, decreasing the air-fuel rich regions by reducing the peak of HF and also reducing the NOx emissions.

Figure 8(a) has reported the influence of separate addition of $\mathrm{H}_{2}$ and $\mathrm{N}_{2}$ gases on soot emission formation. Separate addition of $\mathrm{H}_{2}$ gas due to the higher temperature combustion and replacing part of diesel fuel with a specific amount of hydrogen gas which can decrease the amount of carbon that participates in the combustion process has declined the amount of engine-out soot emission. As can be seen in Figure 8(a), the addition of $8 \% \mathrm{H}_{2}$ of total intake charge has decreased the amount of soot emissions by $89 \%$ in comparison with NDC operation. On the contrary, the addition of $\mathrm{N}_{2}$ gas due to reducing the AFR and the combustion temperature has vastly increased the soot level. According to Figure 7(a), replacing the 8\% $\mathrm{v} / \mathrm{v}$ of total intake charge with the nitrogen gas has considerably increased the soot emission by $146.5 \%$ in comparison with NDC operation due to enlarging the air-fuel rich regions inside the combustion chamber. As illustrated in Figure 8(b), simultaneous addition of $\mathrm{H}_{2}$ (8\% of total intake charge) and $\mathrm{N}_{2}$ (8\% of total intake charge) gases has decreased both peak of HF and the amount of soot emissions by $42.5 \%$. It can be concluded that a single addition of $\mathrm{H}_{2}$ gas has declined the peak of $\mathrm{HF}$, reducing the air-fuel rich regions and as a result soot emissions have considerably diminished. Separate addition of $\mathrm{N}_{2}$ gas has also increased the HF and resulting in high soot emission formation due to the lean air-fuel oxidation process. 
In general, simultaneous addition of $\mathrm{H}_{2}$ and $\mathrm{N}_{2}$ is effective mean to controlling both air-fuel mixing and combustion process.

Figure 9(a) has reported the influence of a separate addition of $\mathrm{N}_{2}$ and $\mathrm{H}_{2}$ gases on $\mathrm{CO}$ emission formation. A single addition of hydrogen gas due to replacing a part of diesel fuel with a specific amount of $\mathrm{H}_{2}$ per cycle has increased the AFR and reduced the carbon concentration, and as a result, $\mathrm{CO}$ emission has vastly decreased. According to Figure $9(\mathrm{a})$, the addition of $8 \% \mathrm{H}_{2} \mathrm{v} / \mathrm{v}$ of the total intake charge, has decreased the amount of CO by $54 \%$ in comparison with NDC operation. In contrary, separate addition of $\mathrm{N}_{2}$ has reduced the AFR and enlarged the air-fuel rich regions inside the combustion chamber which possibly accompanied with lean fuel oxidation process, and as a result, $\mathrm{CO}$ emission has considerably increased. As can be seen in Figure 9(a), replacing the $8 \%$ of v/v of total intake air with $\mathrm{N}_{2}$ gas, has dramatically increased the CO emission by $52 \%$ in comparison with NDC operation. As reported in Figure 9(b), simultaneous addition of $\mathrm{H}_{2}$ (8\% of total intake air) and $\mathrm{N}_{2}$ (8\% of total intake air) has considerably increased the $\mathrm{CO}$ level by $86 \%$ in comparison with NDC operation. It can be concluded that simultaneous addition of $\mathrm{H}_{2}$ and $\mathrm{N}_{2}$ has decreased the oxygen concentration inside the cylinder and as a result, $\mathrm{CO}$ oxidation process has been weakened.

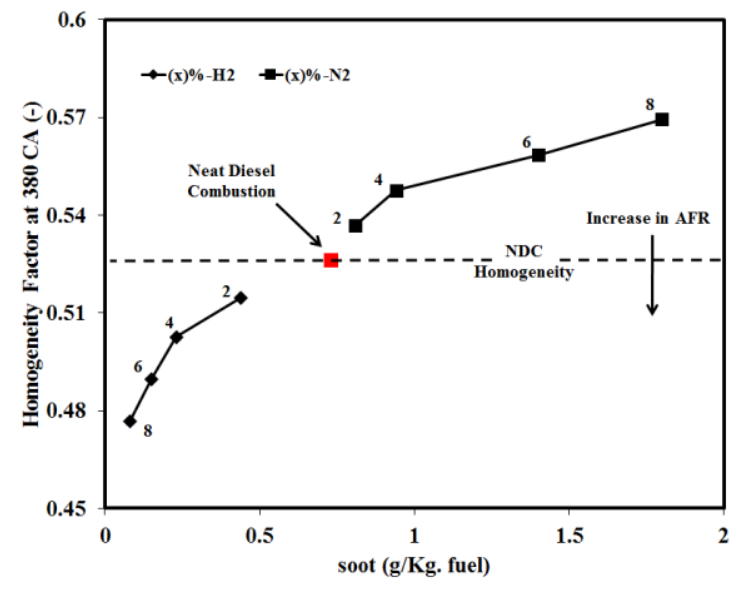

(a)

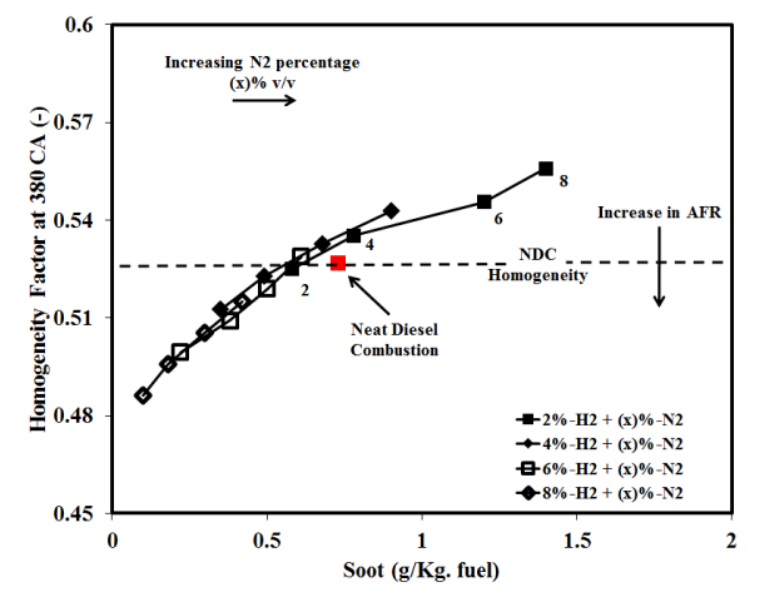

(b)

Figure 8. soot versus HF at $380 \mathrm{CA}$, The effects of separate and simultaneous addition of nitrogen and hydrogen gases on soot emission formation in comparison with NDC operation 


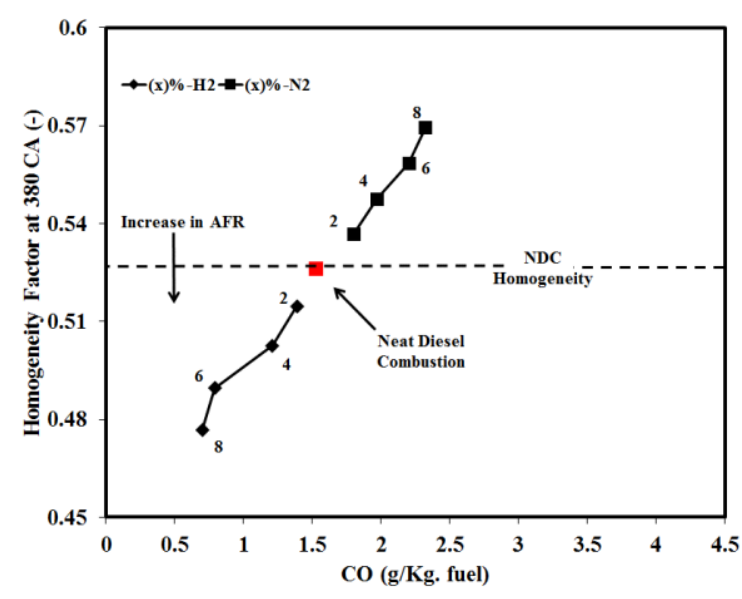

(a)

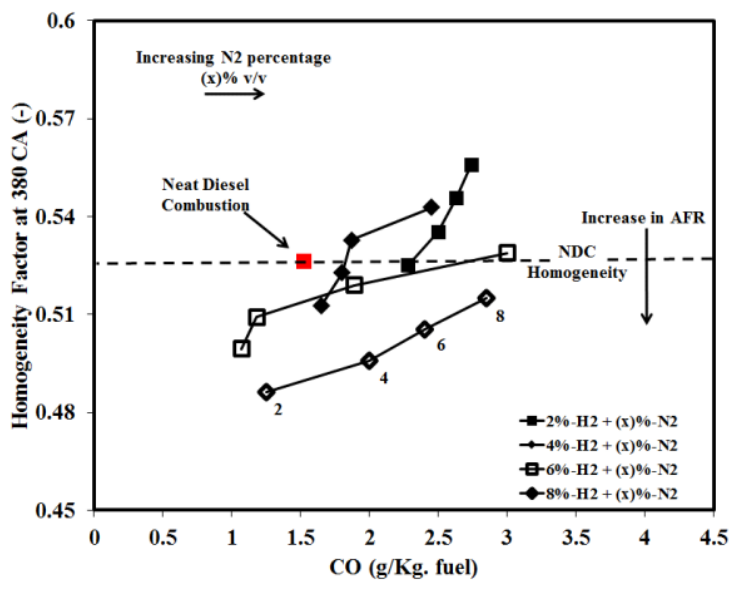

(b)

Figure 9. CO versus $\mathrm{HF}$ at $380 \mathrm{CA}$, The effects of separate and simultaneous addition of nitrogen and hydrogen gases on $\mathrm{CO}$ emission formation in comparison with NDC operation

Figure 10 shows the in-cylinder mean temperature, NOx and soot contours for the separate and simultaneous addition of hydrogen and nitrogen gases in compared with neat diesel combustion at 380 CA. According to the Figure 9, soot and nitrogen oxides are located on both sides of the flame front. Adding hydrogen gas has increased the in-cylinder mean temperature inside the cylinder and the amount of nitrogen oxides. Conversely, the addition of $\mathrm{N}_{2}$ gas has increased the soot emissions and decreased the in-cylinder average temperature. According to the Figure, it can be seen that the inconsistent behaviour of soot and nitrogen oxides emissions. Furthermore, simultaneous addition of $\mathrm{H}_{2}$ and $\mathrm{N}_{2}$ gases has decreased both soot and NOx emissions.
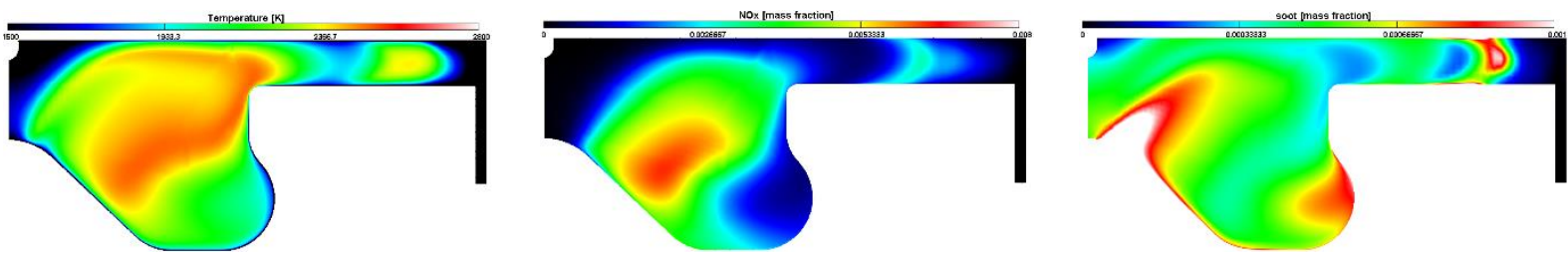

\section{Neat Diesel Combustion}
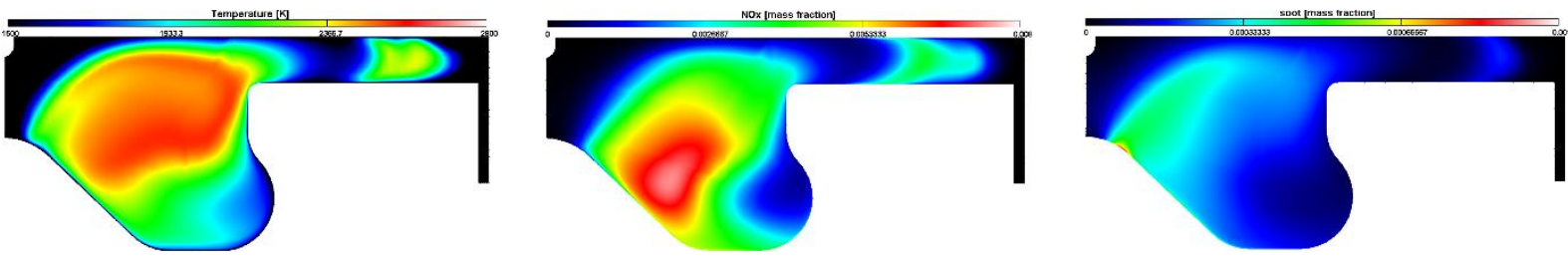

$4 \% \mathrm{H}_{2}$ gas addition 

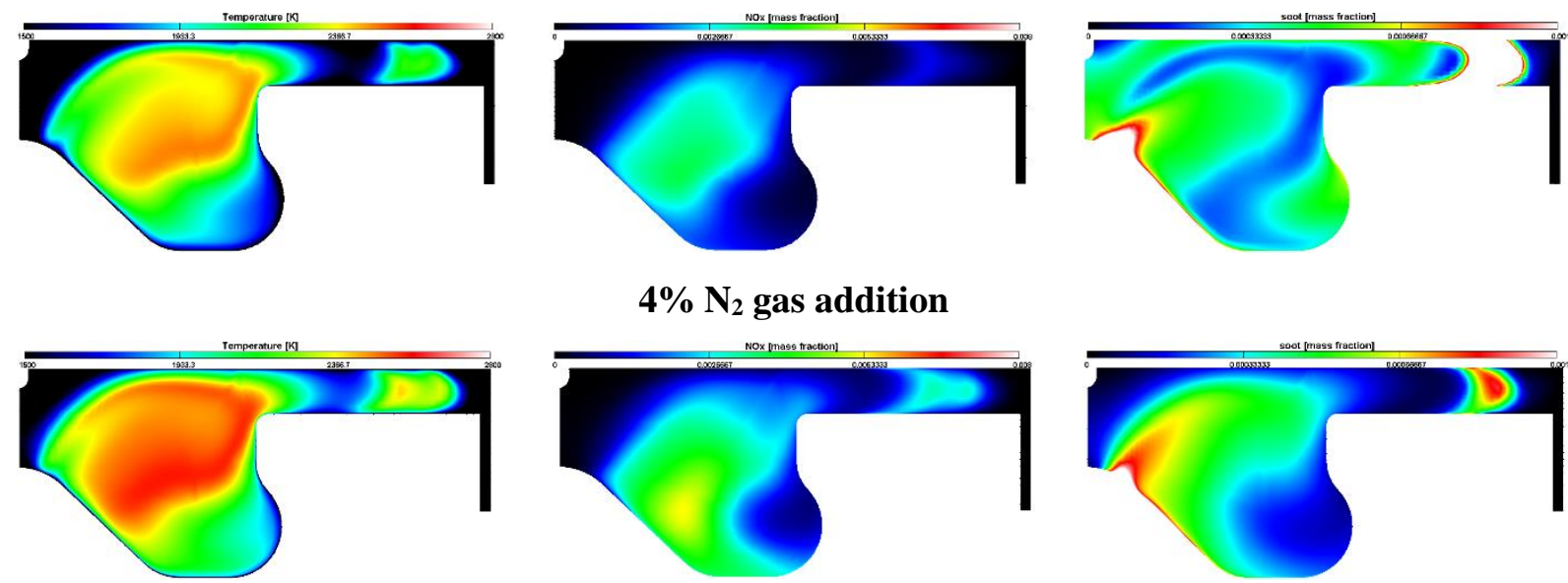

$6 \% \mathrm{H}_{2}+6 \% \mathrm{~N}_{2}$ gas addition

Figure 10. The effects of separate and simultaneous addition of $\mathrm{H}_{2}$ and $\mathrm{N}_{2}$ on in-cylinder mean temperature, NOx and soot emissions in comparison with neat diesel combustion at $380 \mathrm{CA}$

\subsection{Effects of $\mathrm{H}_{2}$ and $\mathrm{N}_{2}$ addition on engine performance}

Figure 11(a) and (b) have reported the effects of separate addition of nitrogen and hydrogen gases on Indicated Specific Energy Consumption (ISEC) and Indicated Power (IP) respectively. Due to high heating value and replacing a part of diesel fuel with a specific amount of hydrogen gas in each operating cycle, separate addition of $\mathrm{H}_{2}$ has considerably decreased ISEC and increased IP due to higher combustion temperature in comparison with NDC operation. According to Figure 11(a) and (b), the addition of $8 \%$ of total intake charge with hydrogen gas has decreased the ISEC by $30 \%$ and increased IP by $19.5 \%$ compared with NDC operation. It can be concluded that, by the addition of hydrogen gas, the AFR and the combustion temperature has increased and following that, the air-fuel oxidation process has improved, and as a result, the ISEC and IP have improved. On the contrary, due to replacing the part of the oxygen content of intake charge with $\mathrm{N}_{2}$ gas that has caused the AFR and in-cylinder mean temperature to be reduced, the addition of nitrogen gas has led to a higher ISEC and lower IP as reported by Figure 11(b). According to Figure 11(b), the addition of $8 \%$ of total intake air with nitrogen gas has increased ISEC by $5 \%$ and decreased the IP by $5 \%$ in comparison with NDC operation. 


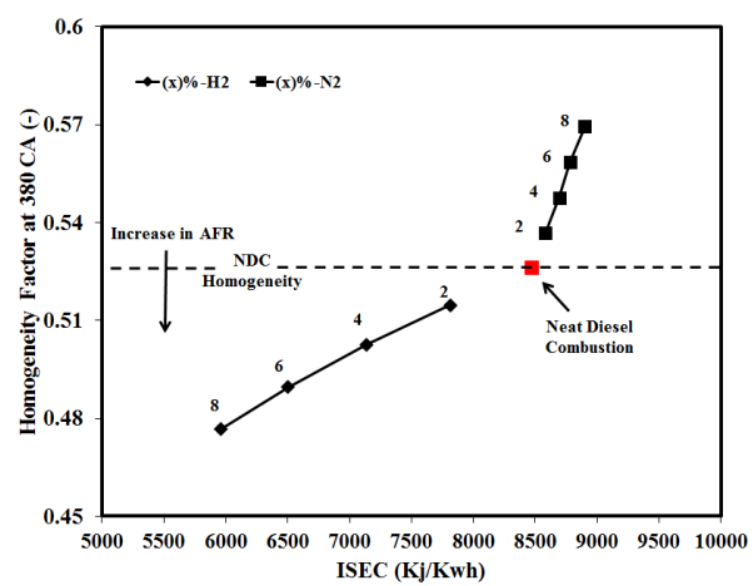

(a)

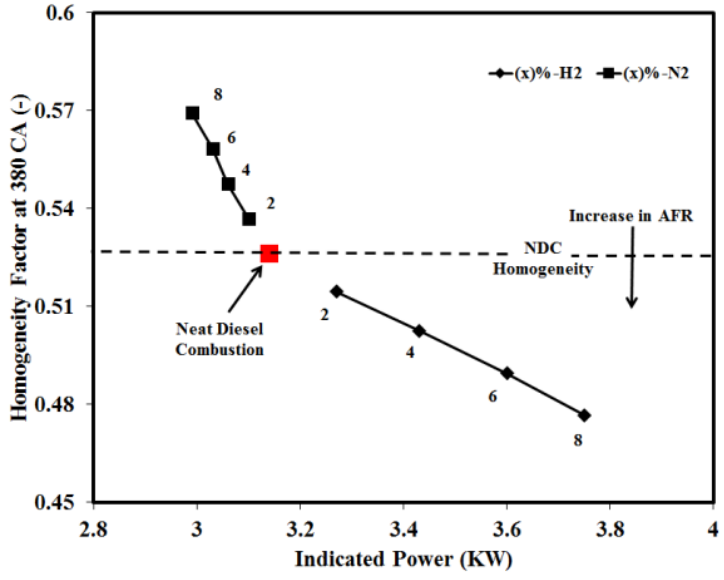

(b)

Figure 11. ISEC and IP versus HF at $380 \mathrm{CA}$, The effects of separate addition of nitrogen and hydrogen gases on ISEC and IP in comparison with NDC operation

Figure 12(a) and (b) have reported the effects of simultaneous addition of $\mathrm{H}_{2}$ and $\mathrm{N}_{2}$ gases on ISEC and IP respectively. As can be seen, simultaneous addition of hydrogen ( $8 \%$ volumetric of total intake charge) and nitrogen (8\% volumetric of total intake charge) has improved both ISEC and IP by $25.7 \%$ and $13 \%$ respectively. It can be concluded that simultaneous addition of both gases, has increased AFR and the combustion temperature and also due to increasing of HF simultaneous with air-fuel rich regions reduction, oxidation process of fuel distributed in the combustion chamber has improved.

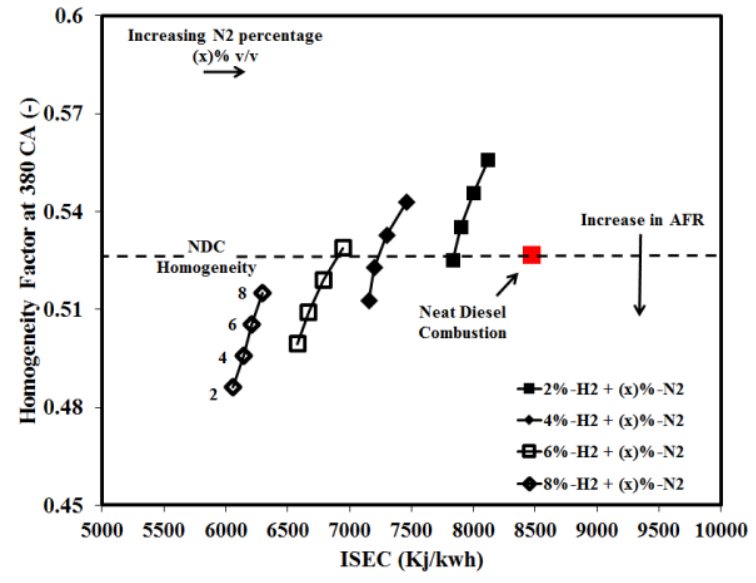

(a)

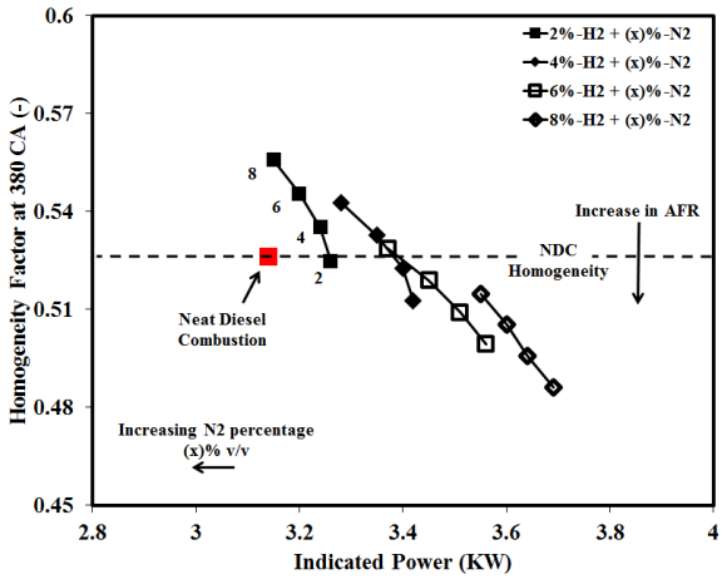

(b)

Figure 12. ISEC and IP versus HF at $380 \mathrm{CA}$, The effects of simultaneous addition of nitrogen and hydrogen gases on ISEC and IP in comparison with NDC operation 


\section{Conclusion}

The aim of this study was exploring the effects of separate and simultaneous addition of hydrogen and nitrogen gases in a high-speed direct injection diesel engine. The study was divided into two parts. The first part dealt with the influence of adding nitrogen and hydrogen gases in the range of 2 to $8 \% \mathrm{v} / \mathrm{v}$ of total intake charge to the combustion chamber with $2 \%$ steps. In the second section, the simultaneous effects of adding nitrogen and hydrogen gases were investigated. The percentage of hydrogen gas $(2,4,6$ and 8 percent) was kept constant, and the volume of nitrogen in the range of 2 to 8 percent with $2 \%$ steps has been increased. Considering the success achieved with validation, the effects of gas addition on combustion characteristics (mean in-cylinder temperature, the rate of heat release, homogeneity factor, and the length of spray penetration), engine performance (indicated specific energy consumption and indicated power of the engine), as well as engine exhaust emissions (Carbon monoxide, soot particles, and nitrogen oxides) were investigated. The results showed that:

- Separate addition of hydrogen gas increased the AFR and LSP because of the replacing a part of diesel fuel with a specific amount of $\mathrm{H}_{2}$ gas. Participation of hydrogen in the combustion process of diesel fuel with air caused higher combustion temperature and heat release rate compared with NDC operation due to considerably high heating value and flame speed. Regarding emissions formation, the introduction of $8 \%$ volumetric of total intake charge with $\mathrm{H}_{2}$ gas to the combustion chamber decreased the soot (89\%) and CO (54\%) emissions but increased NOx by $75 \%$ compared with NDC operation. Furthermore, ISEC shrank by $30 \%$, and IP rose by $19.5 \%$ in comparison with neat diesel combustion.

- A single addition of nitrogen gas decreased the both AFR and LSP due to the part replacing the intake air with $\mathrm{N}_{2}$ and reduced flow rate of sprayed fuel particles respectively. Less oxygen content after the introduction of $\mathrm{N}_{2}$ gas to the cylinder decreased the maximum point of incylinder temperature and the heat release rate compared with NDC operation. Replacing the $8 \%$ of total intake air with $\mathrm{N}_{2}$, caused nitrogen oxides decreased by $51 \%$, but soot and $\mathrm{CO}$ increased by $146.5 \%$ and $86 \%$ respectively in comparison with neat diesel combustion. Regarding performance and efficiency of HSDI diesel engine, ISEC increased, and IP decreased both by nearly $5 \%$ compared with NDC operation.

- Based on the strategy adopted to replace a part of diesel fuel with a certain amount of hydrogen gas, the addition of the mentioned gas in the combustion chamber reduced the maximum point of the homogeneity factor, which resulted in the reduction of the rich air-fuel mixture regions. Furthermore, the oxidation process of diesel fuel particles improved due to increase in AFR and in-cylinder mean temperature. On the contrary, the addition of nitrogen gas increased the peak of 
homogeneity factor followed by an increase in the rich air-fuel mixture regions. The oxidation process of distributed fuel particle inside the combustion chamber weakened due to the decrease in AFR and maximum in-cylinder temperature. In general, Homogeneity Factor (HF) found profitable mean to study the effects of separate and simultaneous addition of $\mathrm{N}_{2}$ and $\mathrm{H}_{2}$ gases on the air-fuel mixture quality.

- Due to the simultaneous increase in AFR and in-cylinder mean temperature and formation of lean air-fuel mixture regions inside the combustion chamber because of a decrease in the peak of HF, simultaneous addition of hydrogen and nitrogen gas was found effective mean to reduce the amount of output emissions and improve engine performance simultaneously. By adding $\mathrm{N}_{2}(8 \%$ of total intake charge) and $\mathrm{H}_{2}$ (8\% of total intake charge) simultaneously, NOx and soot emissions decreased by $11.5 \%$ and $42.5 \%$ respectively, but $\mathrm{CO}$ emission increased by $52 \%$. Regarding performance and efficiency, ISEC and IP improved by $25.7 \%$ and $13 \%$ respectively.

\section{Acknowledgments}

The authors gratefully acknowledge the Iran National Science Foundation (INSF) for their financial support under contract No. 93041805.

\section{References}

1. J.B. Heywood, Internal Combustion Engine Fundamentals, McGraw-Hill, Inc., 1988.

2. L. Postrioti, F. Mariani, M. Battistoni, Experimental and numerical momentum flux evaluation of high pressure Diesel spray, Fuel 98 (2012) 149-163.

3. X. Wang, Z. Huang, O.A. Kuti, et al., Experimental and analytical study on biodiesel and diesel spray characteristics under ultra-high injection pressure, Int. J. Heat Fluid Flow 31 (4) (2010) 659-666.

4. J. Dernotte, C. Hespel, F. Foucher, S. Houillé, C. Mounaïm-Rousselle, Influence of physical fuel properties on the injection rate in a Diesel injector, Fuel 96 (2012) 153-160.

5. S. Shuai, N. Abani, T. Yoshikawa, R.D. Reitz, S.W. Park, Evaluation of the effects of injection timing and rate-shape on diesel low temperature combustion using advanced CFD modeling, Fuel 88 (7) (2009) 1235-1244.

6. Mathivanan, K., Mallikarjuna, J. M., \& Ramesh, A. (2016). Influence of multiple fuel injection strategies on performance and combustion characteristics of a diesel fuelled HCCI engine-An experimental investigation. Experimental Thermal and Fluid Science, 77, 337-346. 
7. Mobasheri R, Peng ZJ, Mirsalim SM. Analysis the effect of advanced injection strategies on engine performance and pollutant emissions in a heavy duty DI diesel engine by CFD modeling. Int J Heat Fluid Flow 2012; 33:59-69.

8. Kim, H. J., Park, S. H., \& Lee, C. S. (2016). Impact of fuel spray angles and injection timing on the combustion and emission characteristics of a high-speed diesel engine. Energy, 107, 572-579.

9. Montgomery DT, Chan M, Chang CT, Farrell PV, Reitz RD, Effect of injector nozzle hole size and number on spray characteristics and the performance of a heavy-duty D.I. diesel engine. SAE technical paper 1996:962002.

10. Fang Q, Fang JH, Zhuang J, Huang Z. Influences of pilot injection and exhaust gas recirculation (EGR) on combustion and emissions in a HCCI-DI combustion engine. Appl Therm Eng 2012; 48: 97-104.

11. Kocsis, M., Joo, S., Briggs, T., and Alger, T., "Impact of Swirl Ratio on Combustion Performance of a Non-Pent Roof Combustion Chamber Engine," SAE Technical Paper 2015-01-0743, 2015, doi: 10.4271/2015-01-0743.

12. Yan, B., Tong, L., Wang, H., Zheng, Z., Qin, Y., \& Yao, M. (2017). Experimental and numerical investigation of the effects of combustion chamber reentrant level on combustion characteristics and thermal efficiency of stoichiometric operation natural gas engine with EGR. Applied Thermal Engineering, 123, 1473-1483.

13. Wang, B., Li, T., Ge, L., \& Ogawa, H. (2016). Optimization of combustion chamber geometry for natural gas engines with diesel micro-pilot-induced ignition. Energy Conversion and Management, 122, 552-563.

14. Salahi, M. M., Esfahanian, V., Gharehghani, A., \& Mirsalim, M. (2017). Investigating the reactivity controlled compression ignition (RCCI) combustion strategy in a natural gas/diesel fueled engine with a pre-chamber. Energy Conversion and Management, 132, 40-53.

15. Rinaldini, C. A., Allesina, G., Pedrazzi, S., Mattarelli, E., Savioli, T., Morselli, N., \& Tartarini, P. (2017). Experimental investigation on a Common Rail Diesel engine partially fuelled by syngas. Energy Conversion and Management, 138, 526-537.

16. Kumar, B. R., \& Saravanan, S. (2016). Effects of Iso-Butanol/diesel and n-pentanol/diesel blends on performance and emissions of a DI diesel engine under premixed LTC (low temperature combustion) mode. Fuel, 170, 49-59.

17. Işık, M. Z., Bayındır, H., İscan, B., \& Aydın, H. (2017). The effect of n-butanol additive on low load combustion, performance and emissions of biodiesel-diesel blend in a heavy duty diesel power generator. Journal of the Energy Institute, 90(2), 174-184. 
18. Krishnan, S. R., Srinivasan, K. K., \& Raihan, M. S. (2016). The effect of injection parameters and boost pressure on diesel-propane dual fuel low temperature combustion in a single-cylinder research engine. Fuel, 184, 490-502.

19. Barrios, C. C., Domínguez-Sáez, A., \& Hormigo, D. (2017). Influence of hydrogen addition on combustion characteristics and particle number and size distribution emissions of a TDI diesel engine. Fuel, 199, 162-168.

20. McWilliam, L., Megaritis, T., and Zhao, H., "Experimental Investigation of the Effects of Combined Hydrogen and Diesel Combustion on the Emissions of a HSDI Diesel Engine," SAE Technical Paper 2008-01-1787, 2008, doi: 10.4271/2008-01-1787.

21. Cho Y, Song S, Chun KM. H2 effects on diesel combustion and emissions with an LPL-EGR system. Int J Hydrogen Energy 2013; 38:9897-906.

22. Karagöz, Y., Güler, İ., Sandalcı, T., Yüksek, L., \& Dalkılıç, A. S. (2016). Effect of hydrogen enrichment on combustion characteristics, emissions and performance of a diesel engine. International journal of hydrogen energy, 41(1), 656-665.

23. Talibi, M., Hellier, P., Balachandran, R., \& Ladommatos, N. (2014). Effect of hydrogen-diesel fuel cocombustion on exhaust emissions with verification using an in-cylinder gas sampling technique. International journal of hydrogen energy, 39(27), 15088-15102.

24. Deb, M., Sastry, G. R. K., Bose, P. K., \& Banerjee, R. (2015). An experimental study on combustion, performance and emission analysis of a single cylinder, 4-stroke DI-diesel engine using hydrogen in dual fuel mode of operation. International journal of hydrogen energy, 40(27), 8586-8598.

25. Sandalc1, T., \& Karagöz, Y. (2014). Experimental investigation of the combustion characteristics, emissions and performance of hydrogen port fuel injection in a diesel engine. International journal of hydrogen energy, 39(32), 18480-18489.

26. Yang, Z., Chu, C., Wang, L., \& Huang, Y. (2015). Effects of H 2 addition on combustion and exhaust emissions in a diesel engine. Fuel, 139, 190-197.

27. Zhou, J. H., Cheung, C. S., \& Leung, C. W. (2014). Combustion, performance, regulated and unregulated emissions of a diesel engine with hydrogen addition. Applied energy, 126, 1-12.

28. Jhang, S. R., Chen, K. S., Lin, S. L., Lin, Y. C., \& Cheng, W. L. (2016). Reducing pollutant emissions from a heavy-duty diesel engine by using hydrogen additions. Fuel, 172, 89-95.

29. An, H., Yang, W. M., Maghbouli, A., Li, J., Chou, S. K., \& Chua, K. J. (2013). A numerical study on a hydrogen assisted diesel engine. International journal of hydrogen energy, 38(6), 2919-2928.

30. Ghazal, O. H. (2013). Performance and combustion characteristic of CI engine fueled with hydrogen enriched diesel. International journal of hydrogen energy, 38(35), 15469-15476. 
31. Talibi, M., Balachandran, R., \& Ladommatos, N. (2017). Influence of combusting methane-hydrogen mixtures on compression-ignition engine exhaust emissions and in-cylinder gas composition. International Journal of Hydrogen Energy, 42(4), 2381-2396.

32. Mansor, M. R. A., Abbood, M. M., \& Mohamad, T. I. (2017). The influence of varying hydrogenmethane-diesel mixture ratio on the combustion characteristics and emissions of a direct injection diesel engine. Fuel, 190, 281-291.

33. Tarabet, L., Lounici, M. S., Loubar, K., Khiari, K., Bouguessa, R., \& Tazerout, M. (2017). Hydrogen supplemented natural gas effect on a DI diesel engine operating under dual fuel mode with a biodiesel pilot fuel. International Journal of Hydrogen Energy.

34. Alrazen, H. A., Talib, A. A., \& Ahmad, K. A. (2016). A two-component CFD studies of the effects of $\mathrm{H}$ 2, CNG, and diesel blend on combustion characteristics and emissions of a diesel engine. International Journal of Hydrogen Energy, 41(24), 10483-10495.

35. Christodoulou, F., \& Megaritis, A. (2014). The effect of reformer gas mixture on the performance and emissions of an HSDI diesel engine. international journal of hydrogen energy, 39(18), 9798-9808.

36. Fire, A. V. L. (2014.1). Users Guide-ICE Physics \& Chemistry.

37. Su, T.F., Patterson, M.A., Reitz, R.D. and Farrell, P.V. "Experimental and Numerical Studies of High Pressure Multiple Injection Sprays”, SAE 960861, 1996.

38. Nordin, N. "Complex Chemistry Modeling of Diesel Spray Combustion”, PhD Thesis, Chalmers University of Technology, 2001.

39. Dukowicz, J.K., 1979. Quasi-Steady Droplet Change in the Presence Of Convection. Informal Report Los Alamos Scientific Laboratory, LA7997-MS.

40. Naber, J.D., Reitz, R.D., 1988. Modeling Engine Spray/Wall Impingement. SAE Paper 880107.

41. Halstead, M., Kirsch, L., Quinn, C., 1977. The auto ignition of hydrocarbon fueled at high temperatures and pressures-fitting of a mathematical model. Combustion and Flame 30, 45-60.

42. Hanjalic K, Popovac M, Hadziabdic M. A robust near-wall elliptic-relaxation eddy-viscosity turbulence model for CFD. Int J Heat Fluid Flow 2004; 25:1047 - 1051.

43. Colin, O., Benkenida, A., 2004. The 3-zones extended coherent flame model (ECFM3Z) for computing premixed/diffusion combustion. Oil Gas Sci. Technol. - Rev. IFP 59 (6), 593-609.

44. Hélie, J., Trouvé, A., 2000. A modified coherent flame model to describe turbulent flame propagation in mixtures with variable composition. Proc. Combust. Inst. 28, 193-201.

45. Priesching, P. Ramusch, G. Ruetz, J. Tatschl, R. “3D-CFD Modeling of Conventional and Alternative Diesel Combustion and Pollutant Formation - A Validation Study” , SAE Technical Paper 2007-01-1907, 2007, DOI: 10.4271/2007-01-1907. 
46. Merker, G. P., Schwarz, C., \& Teichmann, R. (n.d.). Combustion engines development: Mixture formation, combustion, emissions and simulation.

47. Nishida, K. and Hiroyasu, H., "Simplified Three-Dimensional Modeling of Mixture Formation and Combustion in a D.I. Diesel Engine,” SAE Technical Paper 890269, 1989.

48. Nandha, K. and Abraham, J., "Dependence of Fuel-Air Mixing Characteristics on Injection Timing in an Early- Injection Diesel Engine,” SAE Technical Paper 2002-01- 0944, 2002, doi:10.4271/2002-010944.

49. Mobasheri, R. and Peng, Z., (2013) "CFD Investigation into Diesel Fuel Injection Schemes with Aid of Homogeneity Factor", Computers and Fluids, 77. pp. 12-23.

50. Peng, Z., Liu, B., Tian, L., and Lu, L., “Analysis of Homogeneity Factor for Diesel PCCI Combustion Control," SAE Technical Paper 2011-01-1832, 2011.

51. Christodoulou, F. (2014). Hydrogen, nitrogen and syngas enriched diesel combustion (Doctoral dissertation), Brunel University. 